Filogeografia e Diversidade Genética do gênero Noctilio (Chiroptera:

Noctilionidae) 


\section{Filogeografia e Diversidade Genética do gênero Noctilio (Chiroptera: Noctilionidae)}

Dissertação apresentada ao Instituto de Biociências da Universidade de São Paulo, para a obtenção de Título de Mestre em Ciências, na Área de Genética e Biologia Evolutiva.

Orientador(a): Prof. Dr. João Stenghel Morgante

SÃO PAULO 
Pavan, Ana Carolina

Filogeografia e Diversidade Genética do gênero Noctilio (Chiroptera: Noctilionidae)

71 páginas

Dissertação (Mestrado) - Instituto de Biociências da Universidade de São Paulo. Departamento de Genética e Biologia Evolutiva.

1. Morcegos 2. Filogeografia 3. Família Noctilionidae. Universidade de São Paulo. Instituto de Biociências. Departamento de Genética e Biologia Evolutiva.

\section{Comissão Julgadora:}

Prof(a). Dr(a).

Prof(a). Dr(a).

Prof. Dr. João Stenghel Morgante

Orientador 


\section{Agradecimentos}

Nada do que conquistei até hoje teria sido possível sem o apoio incondicional de vocês: pai e mãe, obrigada por tudo!

Ao meu orientador, João Stenghel Morgante, pela confiança que depositou em mim, pelos ensinamentos e suporte dado desde o início.

Aos amigos do LABEC: Felipe, Carol, Marcinha, Ju, Gi, Ná, Bia, Fezinha, Kelly, Rodrigo e Latino, com os quais passei grande parte do meu tempo nesses dois anos, obrigada não só pela ajuda, mas pela companhia, amizade e por todos os bons momentos que passamos juntos! Felipe e Carol, muito obrigada pela paciência e por todas as sugestões que me deram.

À minha irmã Mima (seria estranho me referir a você como Silvia!) pela presença constante na minha vida. Afinal, também temos em comum o amor pela Biologia! Obrigada a você e ao Pedro por todas as idéias e momentos compartilhados.

Ao Prof. Dr. Albert David Ditchfield, por toda força dada no início do projeto, e pelas constantes sugestões no decorrer do mestrado.

Ao meu primo Dante, pela "acolhida" em São Paulo e por tudo que me ensinou desde então.

Aos Professores Dr. Diogo Meyer e Dr. Fernando Marques, pelas sugestões nas análises dos resultados.

Às minhas queridas amigas da faculdade, Bia, Ju, Carlinha, Rafa e Sil: adoro vocês! E às minhas amigas de São Paulo: Dri e Helena, por todos os sábados ou domingos que nos divertimos juntas, ou mesmo pelos bons momentos na academia!

Aos pesquisadores e instituições de pesquisa que forneceram amostras, tornando possível a realização desse projeto: Prof. Dr. Albert Ditchfield - LABEQ/UFES; Dr. Fabrício Santos e Dr. Rodrigo Redondo -LBEM/UFMG; Ana Carolina Martins - IEPA; Eliana Gimenez e Katarine Santos - UFPB; Paulo Bobrowiec - INPA; Thieres Pinto - AQUASIS/CE; Adalberto Césari - MZUSP; James L. Patton - MVZ; Burton K. Lim - ROM, Bruce Patterson - FMNH.

A todas as pessoas - família, amigos e colegas - que estiveram presentes na minha vida no decorrer desse período. Saibam que todos foram fundamentais e de alguma maneira contribuíram na realização deste trabalho.

Por fim, a CAPES (Coordenação de Aperfeiçoamento de Pessoal de Nível Superior), pela bolsa concedida, e a FAPESP (Fundação de Amparo à Pesquisa do Estado de São Paulo) pelo financiamento do projeto (processo no 05/55438-4). 


\section{Índice}

$\begin{array}{ll}\text { Resumo } & 01\end{array}$

$\begin{array}{ll}\text { Abstract } & 02\end{array}$

$\begin{array}{ll}\text { I - Introdução } & 03\end{array}$

$\begin{array}{ll}\text { 1. Objeto do estudo } & 04\end{array}$

$\begin{array}{ll}\text { 2. Filogeografia intraespecífica } & 08\end{array}$

$\begin{array}{ll}\text { II - Objetivos } & 15\end{array}$

III - Material e Métodos 16

$\begin{array}{ll}\text { 1. Material } & 16\end{array}$

2. Métodos 19

IV - Resultados

1. Análises Intraespecíficas 25

2. Análises Filogenéticas 30

3. Estimativas para o tempo de divergência 42

V - Discussão

1. Filogeografia de Noctilio leporinus 44

2. Filogeografia de Noctilio albiventris 46

3. Origem das linhagens evolutivas do gênero Noctilio 50

VI - Conclusões

$\begin{array}{ll}\text { VII - Anexo } & 58\end{array}$

VIII - Referências Bibliográficas $\quad 66$ 


\section{INTRODUÇÃO}

Os morcegos compõem um grupo de mamíferos muito bem sucedido, constituído por 18 famílias, 186 gêneros e 1100 espécies (Simmons, 2005). A ordem Chiroptera tem uma distribuição mundial, estando ausente somente nas regiões polares e algumas ilhas oceânicas isoladas. Apesar de serem abundantes em faunas de clima temperado, a densidade e riqueza de espécies de morcegos alcançam seus maiores valores nas áreas tropicais e subtropicais. Tal disparidade entre os continentes norte e sul e o alto grau de endemismo da fauna de morcegos da região Neotropical podem ser atribuídos, em parte, às condições biogeográficas desta região. A América do Sul, existindo como uma ilha desde o Cretáceo até o Cenozóico tardio, pode ter oferecido uma grande oportunidade para a radiação dos morcegos.

A ordem Chiroptera encontra-se dividida em duas subordens marcantes: Megachiroptera, com apenas uma família - Pteropodidae - e Microchiroptera, que inclui as demais 17 famílias (Vaughan, 2000). Nenhum outro grupo de mamíferos atingiu a diversidade de hábitos alimentares encontrada em Chiroptera, incluindo uma especialização única dentre os Tetrapoda, a hematofagia. Dentro de Microchiroptera encontra-se a superfamilia Noctilionoidea, que inclui a maior família Neotropical, Phyllostomidae, composta por 49 gêneros e aproximadamente 140 espécies, além das famílias Noctilionidae, Mormoopidae, Furipteridae, Thyropteridae, Mystacinidae e Myzopodidae. Noctilionoidea representa o grupo de morcegos que exibe a maior diversidade de hábitos alimentares, incluindo insetivoria, omnivoria, frugivoria, nectarivoria, carnivoria, hematofagia e piscivoria (Ferrarezzi \& Gimenez, 1996). Especializações para a exploração destas diferentes fontes alimentares requerem uma ampla diversificação nas adaptações morfológicas e comportamentais relacionadas a tais estratégias, o que acarretou na grande diversidade de formas encontradas em Chiroptera. Como conseqüência, a importância ecológica dos morcegos não pode ser minimizada, visto que em uma localidade qualquer de floresta Neotropical, mais de metade das espécies de mamíferos listados serão morcegos (Voss e Emmons, 1996). 


\section{Objeto do estudo}

A família Noctilionidae possui somente um gênero, Noctilio Linnaeus, 1766, no qual, atualmente, são reconhecidas duas espécies: $N$. leporinus e $N$. albiventris, ambas distribuídas nas planícies da América Latina (Hood e Jones, 1984). Noctilio albiventris Desmarest, 1818 é encontrado desde o Sul da Guatemala até o Norte da Argentina e Uruguai. Noctilio leporinus (Linnaeus, 1758) ocorre a partir da Costa Pacífica do México e Cuba, incluindo a maioria das ilhas do Caribe, até o Norte da Argentina e Uruguai (Emmons, 1990; Hood e Jones, 1984). A distribuição de N. leporinus é descontínua, estando majoritariamente restrita a terras baixas não-áridas e regiões costeiras, além de acompanhar as maiores bacias fluviais (Hood e Jones, 1984).

Evidências paleontológicas para a família Noctilionidae, assim como para outros grupos de morcegos, são escassas. O primeiro registro de fósseis de morcegos do período terciário na bacia do rio Amazonas foi feito por Czaplewski (1996). O trabalho descreve a fauna fóssil do Conglomerado do Acre, no sudoeste da bacia amazônica, datada entre 9 e 5 milhões de anos atrás (Mioceno tardio). Um dos fósseis encontrados, por se tratar de um molar com características presentes apenas em noctilionídeos modernos, foi descrito como uma nova espécie, Noctilio lacrimaelunaris. Complementarmente, Czaplewski (1997) descreve a ocorrência de dentes fósseis de $N$. albiventris pertencentes à fauna de La Venta, Colômbia e que datam de 12,5 milhões de anos atrás. Para N. leporinus são conhecidos apenas registros fósseis em Cuba e Porto Rico, que datam do Pleistoceno tardio (Martin, 1972).

$N$. leporinus possui pés robustos, extremamente diagnósticos da espécie, com tamanho superior a 25mm (Hood e Jones, 1984), e longas garras curvadas e achatadas lateralmente, tornando-o apto para a pesca. Sua envergadura é de aproximadamente $500 \mathrm{~mm}$, o comprimento do antebraço excede $75 \mathrm{~mm}$ e seu peso é superior a $50 \mathrm{~g}$ (Hood e Jones, 1984). Possui pelagem extremamente curta, com coloração do dorso variada, desde o laranja, passando pelo marrom, até o cinza prateado. A região ventral apresenta uma coloração mais pálida. Possui orelhas separadas, alongadas e estreitas, e sua cauda, mais curta que o uropatágio, encontra-se inserida neste, com apenas a extremidade distal emergindo na superfície superior (Emmons, 1990). 
Além de N. leporinus, outras espécies como Myotis vivesi (Vespertilionidae), Megaderma lyra (Megadermatidae) e Nycteris grandis (Nycteridae) também incluem peixes em sua dieta (Nowak, 1994). Contudo, N. leporinus é considerado o morcego de hábito alimentar piscívoro melhor estudado, embora se saiba que sua dieta inclui quase ou a mesma quantidade de insetos que de peixes, além de alguns tipos de crustáceos e aracnídeos (Brooke, 1994). Um estudo sobre a dieta da espécie na Baía de Guaratuba, PR (Bordignon, 2001) mostrou um consumo de peixes constante ao longo do ano, com uma freqüência de ocorrência deste item alimentar em $92 \%$ das fezes analisadas. O consumo de insetos apresentou uma maior variação sazonal, com freqüências baixas à total ausência nos meses de inverno, e um aumento de freqüência nos meses decorrentes, alcançando $100 \%$ em Novembro.

$N$. albiventris se assemelha a $N$. leporinus na maioria das características morfológicas externas e craniais, porém apresenta menor porte, atingindo até $400 \mathrm{~mm}$ de envergadura, com um peso máximo de $40 \mathrm{~g}$ (Hood e Pitocchelli, 1983). N. albiventris apresenta pés menos robustos, com tamanho menor que $20 \mathrm{~mm}$, e comprimento do antebraço inferior a $70 \mathrm{~mm}$. Ao contrário do grupo-irmão, N. albiventris é primariamente insetívoro, podendo capturar insetos em vôo ou sobre a superfície da água. Ambas as espécies são caracterizadas pela presença de bolsas internas nas bochechas, que são formadas por expansões posterolaterais do músculo bucinador e se estendem caudalmente, cobrindo uma larga porção do músculo masseter. Estas são utilizadas primariamente para a estocagem de alimento durante o forrageamento. Dessa maneira, um peixe capturado por $N$. leporinus, por exemplo, é parcialmente mastigado e imediatamente armazenado nas bolsas, o que permite ao animal a continuidade da pesca numa dada localidade, aumentando assim sua eficiência de forrageamento (Hood e Jones, 1984). Tais bolsas podem ser visualizadas externamente pelos lábios com várias dobras pendentes, o que Ihes dá uma face semelhante à de um cachorro (bulldog bats).

$N$. leporinus é um dos poucos morcegos em cuja linhagem surgiu a piscivoria e esta estratégia alimentar já foi investigada em alguns trabalhos. Bloedel (1955) analisou os métodos de caça utilizados por morcegos-pescadores, particularmente N. leporinus, e demonstrou que este utiliza suas garras afiadas para retirar o peixe da água, ao invés da membrana interfemoral, como se propunha anteriormente. As adaptações para o hábito alimentar em $N$. leporinus não se restringem somente à morfologia externa. Várias 
modificações funcionais no trato digestivo estão associadas à piscivoria, como diferenças na musculatura do esfíncter cardíaco (permite o armazenamento de grandes itens alimentares) e nas características histoquímicas do estômago (Forman, 1973).

Regiões de águas calmas são mais propícias para se encontrar Noctilio leporinus, pois permitem que o animal pesque mais facilmente. Podem formar colônias de centenas de indivíduos, que são encontradas freqüentemente em troncos ocos de árvores e cavernas rochosas próximas a corpos d'água. $N$. albiventris forma abrigos em ocos de árvores e construções, tais como pontes e viadutos, tendo sido encontrado em grande número com espécies do gênero Molossus (Hood e Pitocchelli, 1983). Nogueira e Pol (1998) observaram a co-ocupação de abrigos entre indivíduos de N. albiventris e Rhynchonycteris naso, um morcego insetívoro de pequeno porte. A formação de colônias nas duas espécies ocorre por agregamento conforme o sexo ou maturidade sexual (Goodwin e Greenhall, 1961; Carter et al., 1966). Entretanto, machos e fêmeas, assim como adultos e juvenis, já foram encontrados juntos em refúgios (Jones et al., 1973; Silva Taboada, 1979). Indivíduos ou colônias de $N$. leporinus também podem ser encontrados descansando com outras espécies de morcegos. Para colônias que ocupam troncos de árvores, Goodwin e Greenhall (1961) observaram sua ocupação conjunta com Desmodus rotundus, de hábito hematófago. Já para cavernas, alguns trabalhos citam $N$. leporinus associado com várias espécies, dentre as quais $D$. rotundus, Carollia perspicillata, Glossophaga soricina e Mormoops megalophylla (Goodwin e Greenhall, 1961; Silva Taboada, 1979)

As duas espécies possuem a estrutura geral e o padrão dos sinais de ecolocação similares, utilizando pulsos com componentes curtos de freqüência constante precedendo um componente de freqüência modulada, denominado FM sweep (Kalko et al., 1998). As estratégias de forrageamento adotadas também são semelhantes, mas diferem na freqüência com que são utilizadas em cada espécie. Em geral, capturas aéreas e mergulhos a partir da busca por presas sobre a água - high search flight - são mais comuns em $N$. albiventris enquanto mergulhos a partir de diferentes alturas da água - high search e low search flight - e buscas aleatórias, sem um alvo específico, denominadas random rakes, predominam em $N$. leporinus. Como exemplo da distinção existente no comportamento de forrageio das duas espécies, insetos que quase inevitavelmente levariam a um mergulho para captura em $N$. albiventris, não provocam tal iniciativa em $N$. leporinus (Kalko et al., 1998) 
O padrão de atividades de $N$. albiventris inclui um pico inicial ao anoitecer, e um segundo após a meia-noite (Brown, 1968), com o forrageio nesta espécie ocorrendo em pequenos grupos sobre rios e córregos. Este padrão difere daquele de $N$. leporinus, que forrageia de maneira uniforme ao longo da noite, fazendo com que as duas espécies forrageiem nas mesmas áreas, utilizando-as, porém, de maneiras distintas. Hooper e Brown (1968) sugeriram que essa separação temporal na atividade contribuiu para diferenças na dieta e reprodução das duas espécies, facilitando sua simpatria.

São poucos os estudos detalhados quanto à reprodução das duas espécies. Hooper e Brown (1968) sugerem que N. albiventris tem uma estação reprodutiva mais bem definida que $N$. leporinus, com os filhotes nascendo mais tardiamente no ano. Geralmente, as fêmeas de Noctilio são monoestrais e dão à luz um único filhote por gravidez (Hood e Pitocchelli, 1983; Hood e Jones, 1984). A maioria dos dados disponíveis é referente ao Hemisfério Norte e sugere um padrão sazonal geral, com o período reprodutivo se iniciando em Novembro ou Dezembro, gestação se estendendo durante o inverno e início da primavera e nascimento do filhote entre Abril e Junho. No entanto, Hood e Jones (1984) apontam a existência de um segundo pico reprodutivo no ano.

Bordignon (2001), ao investigar os aspectos reprodutivos da população de $N$. leporinus na Baía de Guaratuba, no litoral do estado do Paraná, observou que a espécie se acasala com maior freqüência na primavera e que o recrutamento de juvenis, ou seja, o aparecimento de jovens em freqüências elevadas na população, ocorre a partir do final do verão. Entretanto, o autor demonstrou que possivelmente a espécie pode se acasalar em qualquer período do ano. Tal afirmação teve como evidências a ausência de regressão testicular nos machos e a presença constante de fêmeas lactantes ao longo do ano. Adicionalmente, ao estudar a variação na coloração da pelagem, o autor encontrou uma diferença gradativa na cor dos pêlos em $N$. leporinus, tanto em machos como em fêmeas, e demonstrou que esta diferença tende a acompanhar, de maneira geral, o amadurecimento sexual dos exemplares estudados, evidenciado pelo aumento de peso e pelos caracteres sexuais secundários. Sendo assim, sugeriu que a cor da pelagem em $N$. leporinus, quando correlacionado com o peso corporal, pode vir a ser utilizado como um caractere auxiliar na determinação da maturidade sexual. 


\section{Filogeografia intraespecífica}

O termo 'Filogeografia' se refere ao estudo dos princípios e processos que governam a distribuição geográfica das linhagens genealógicas dentro de uma espécie, ou em espécies próximas (Avise, 1994, 2000). O DNA mitocondrial (DNAmit), devido à suas características únicas - ausência de seqüências não codificantes e de recombinação, herança predominantemente materna e alta taxa de evolução - é um marcador molecular extremamente informativo em estudos evolutivos, por sua capacidade de caracterizar a variabilidade inter e intraespecífica, identificar espécies e populações, e estimar relações filogenéticas (Avise 1994, 2000). Geralmente, a localização de linhagens de DNAmit aparentadas na maioria das espécies reflete um fluxo gênico contemporâneo limitado, e a presença de quebras genéticas profundas pode ser evidência de uma separação e isolamento histórico entre as mesmas (Avise, 2000). A utilização do DNAmit para estudos filogeográficos baseia-se em dois aspectos da sua variabilidade intraespecífica: estrutura hierárquica, ou seja, magnitude e padrão de divergência filogenética do DNAmit; e partição geográfica, ou grau de subdivisão geográfica dos agrupamentos filogenéticos (clados) (Ditchfield, 1996; Ditchfield e Burns, 1998).

As análises filogeográficas têm representado uma nova base explicativa para eventos biogeográficos. Tais estudos possibilitam o teste de modelos alternativos de especiação e a identificação de quebras filogeográficas comuns para diferentes táxons. A observação de padrões comuns em táxons independentes é interessante do ponto de vista biogeográfico, pois estes são mais parcimoniosamente explicados pela ocorrência de eventos climáticos ou geológicos, afetando o conjunto de espécies, do que por eventos particulares, afetando cada táxon separadamente. Essa concordância possibilita a determinação de limites biogeográficos e eventos históricos comuns numa região.

Em geral, tanto fatores biogeográficos e demográficos históricos como comportamento e ecologia contemporâneos influenciam na distribuição geográfica e estruturação da variação genética de uma espécie (Avise, 2000). Como exemplo, diferenças na habilidade de dispersão da espécie parecem exercer grande influência nos padrões de estruturação filogeográfica do DNAmit (Avise, 1989). Dessa maneira, os morcegos, apesar de serem mamíferos de pequeno porte, geralmente não possuem padrões geograficamente circunscritos de distribuição de linhagens, como encontrados em roedores ou marsupiais, 
pelo fato de serem alados. As asas Ihes possibilitam uma capacidade de transpor barreiras, tais quais rios e montanhas, que pequenos mamíferos terrestres normalmente não conseguem vencer. Como conseqüência, o fluxo gênico entre populações de morcegos é potencialmente grande. A capacidade de dispersão, entretanto, não implica necessariamente no deslocamento por longas distâncias. Outros fatores influenciam no padrão de distribuição geográfica de uma espécie, como o hábito alimentar e a estratégia de forrageio adotada. Contudo, as espécies de morcegos geralmente apresentam um baixo nível de divergência genética entre indivíduos de populações geograficamente distantes.

Neste contexto estão inseridos diversos trabalhos que investigam padrões filogeográficos de espécies de vertebrados e utilizam hipóteses biogeográficas de ampla aceitação para explicá-los. Uma questão freqüentemente discutida em tais trabalhos refere-se à relação de parentesco existente entre táxons das áreas de Floresta Atlântica e Amazônica (Cracraft \& Prum, 1988; Bates et al.,1998; Patton et al., 2000). Costa (2003) utilizou a variação genética do gene mitocondrial citocromo $b$ para examinar como a diversidade genética dos táxons florestais de pequenos mamíferos terrestres estudados está distribuída entre e dentro destes dois biomas florestais, assim como na região de transição entre eles, a partir de inferências das relações entre genealogias e geografia. Assim como em outros casos, foi encontrado em alguns táxons que seus clados amazônicos estavam mais próximos filogeneticamente a clados da Floresta Atlântica do que a outros clados da região Amazônica.

Os estudos filogeográficos em morcegos têm crescido consideravelmente nos últimos anos. O primeiro deles realizado com espécies neotropicais (Ditchfield, 2000) buscou descrever um padrão filogeográfico geral para morcegos. Seu principal objetivo foi observar a variação populacional e estrutura geográfica de algumas espécies neotropicais, comparando seus padrões filogeográficos com aqueles descritos na literatura para outros táxons, como pequenos mamíferos (roedores e marsupiais) e aves. Como resultado foram encontrados baixos índices de divergência nucleotídica (1 - 4\%) em 17 espécies de morcegos, com pouca ou nenhuma circunscrição geográfica das populações. O grau de divergência intraespecífica em morcegos chega a ser até 10 vezes inferior ao de pequenos mamíferos, assemelhando-se ao padrão descrito para aves (Ditchfield e Burns, 1998; Ditchfield, 2000). Estudos posteriores em outros táxons de morcegos mostraram resultados 
semelhantes. Hoffmann e Baker (2001), ao descrever a diversidade genética do gênero Glossophaga, encontraram valores de divergência intraespecífica entre 0,7 e 2,2\% para quatro das cinco espécies estudadas. Em Glossophaga soricina, porém, foram encontradas duas linhagens bem suportadas, divergindo em média $6 \%$. Um dos clados correspondia a indivíduos da América do Sul a leste dos Andes, enquanto o outro agrupava América do Norte e Central, e costa oeste dos Andes. Os autores destacaram a ocorrência simpátrica dos clados no Peru. Para o gênero Carollia, Hoffmann e Baker (2003) encontraram valores muito similares aos descritos por Ditchfield (2000), em quatro das cinco espécies do gênero. Já Carollia castanea apresentou valores elevados de divergência genética entre seus clados, superiores a $5 \%$. Em ambos os casos o processo de diversificação intraespecífica era congruente com eventos pré-pleistocênicos. Uma outra exceção é o morcego hematófago Desmodus rotundus. Martins e colaboradores (2007) encontraram clados altamente estruturados, correspondendo aos diferentes biomas brasileiros. A divergência dentro dessa espécie foi de até $11,8 \%$, com o tempo de diversificação dos clados remetendo ao Pleistoceno.

O gênero Noctilio, incluindo suas duas espécies atuais, $N$. leporinus e $N$. albiventris, tem poucos estudos genéticos realizados. O táxon nunca foi incluído em estudos filogeográficos, e suas relações filogenéticas não são totalmente elucidadas. Davis (1973) realizou a descrição da variação geográfica para $N$. leporinus baseado no estudo morfológico de 388 indivíduos ao longo de sua distribuição geográfica, incluindo, porém, apenas a bacia Amazônica dentro da divisão política brasileira (Figura 1a). O autor reconheceu três regiões geográficas de diferenciação para a espécie. Segundo ele, ao longo da distribuição da espécie, foi observada a ocorrência de indivíduos maiores nos extremos Norte e Sul, enquanto na Bacia Amazônica foram encontrados indivíduos de menor tamanho, e assim propôs a existência de três subespécies para o táxon: $\mathrm{N}$. I. mastivus (Vahl, 1797), N. I. rufescens Olfers, 1818 e N. I. leporinus (Linnaeus, 1758) (Figura 1b). 
INTRODUÇÃO
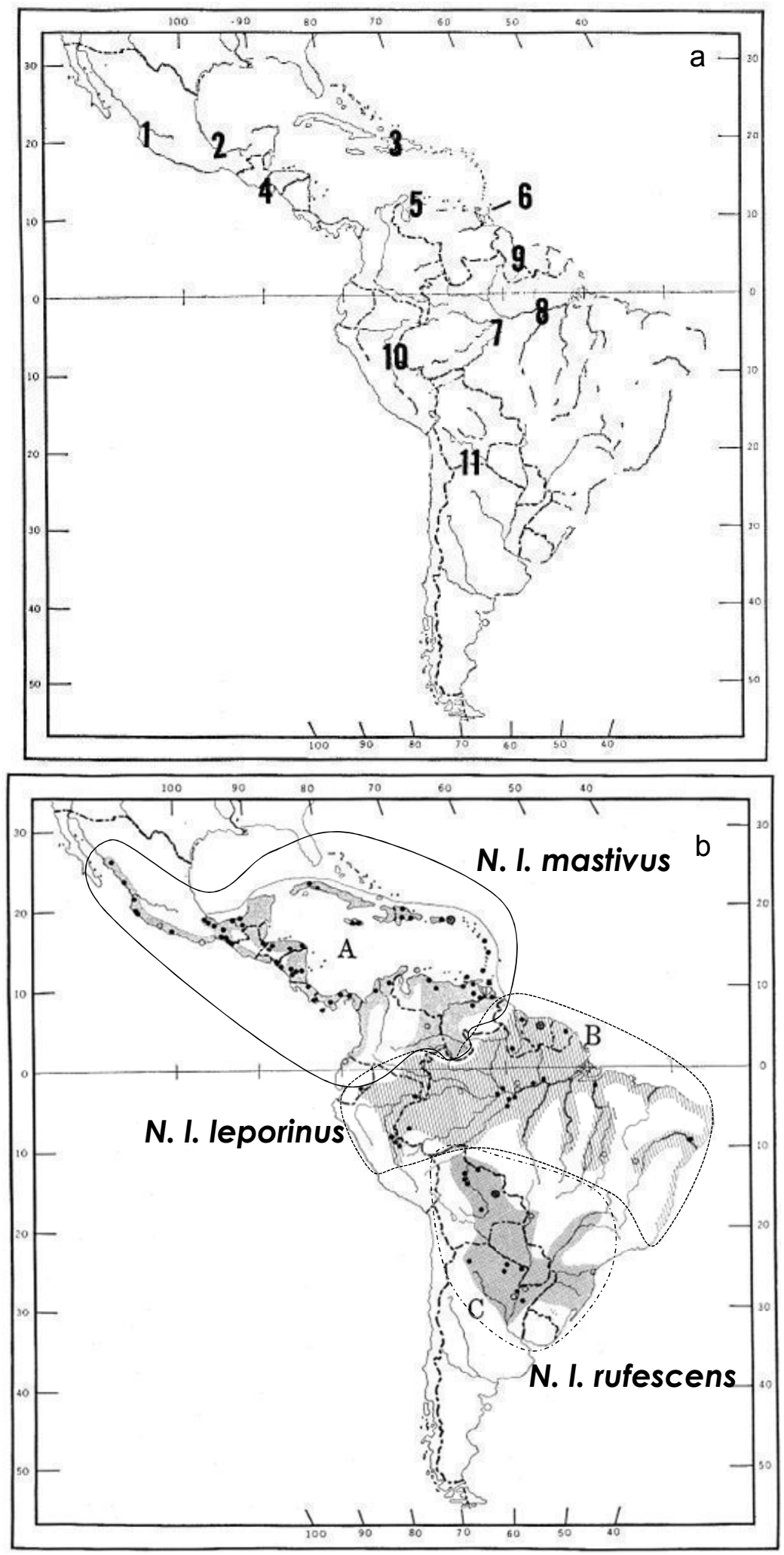

Figura 1. Localidades amostradas por Davis (1973) para analise da variação geográfica em Noctilio leporinus (a) e distribuição geográfica das subespécies propostas (b). A: N. I. mastivus; B: N. I. leporinus; C: N. I. rufescens. Círculos pretos: pontos amostrados; Círculos abertos: registros publicados na literatura. 
Posteriormente, ao fazer uma revisão taxonômica em N. albiventris, Davis (1976) analisou os caracteres morfológicos de 537 espécimes de 11 áreas distintas na tentativa de descrever a variação geográfica para a espécie (Figura 2a). Como resultados, o autor ressaltou o fato dos indivíduos das localidades da Bolivia, Colômbia e leste do Peru (regiões 9, 10 e 11) sempre segregarem como um grupo homogêneo, caracterizado pelo seu tamanho superior se comparado aos demais, além da coloração mais escura e ausência da listra dorsal, ou a presença da mesma de forma pouco discernível. Adicionalmente, também foi destacado o tamanho consideravelmente menor dos indivíduos das diversas localidades amostradas na foz dos rios Amazonas, Xingú, Negro e Tapajós, na Baixa Bacia Amazônica (áreas 6 e 7), onde as médias de algumas medidas foram inferiores aos desvios padrões das médias encontradas para Honduras e Nicarágua (área 1 - padrão). Por fim, a análise de todos os dados revelou uma contínua redução de valores nas medidas dos indivíduos da área 1 para aqueles do Panamá e noroeste da Colômbia (área 3), e a ocorrência de uma "quebra" nesta continuidade na Venezuela (área 4), entre o lago Maracaíbo e as proximidades de Caracas. Nesta região foram encontrados indivíduos com medidas comparáveis aquelas obtidas para as áreas 9,10 e 11, com as localidades da Guiana (área 5) tornando a apresentar indivíduos menores. As amostras do sul do Brasil, Paraguai e Argentina (área 8) apresentaram valores intermediários, comparáveis aos observados para a America Central (áreas 1 a 3). Neste contexto, Davis (1976) reconheceu quatro áreas de diferenciação para a espécie ao longo de sua distribuição, propondo a existência de quatro subespécies: $N$. a. albiventris (Desmarest, 1818), N. a. minor (Osgood, 1910), N. a. affinis (D'Orbigny, 1836) e N. a. cabrerai (Davis, 1976) (Figura 2b).

Já em trabalho realizado em 2001, Lewis-Oritt e colaboradores examinaram as relações filogenéticas para o gênero Noctilio utilizando a seqüência completa do gene mitocondrial citocromo $b$ e um fragmento de 1398pb do gene nuclear RAG2. Foram utilizados 10 indivíduos de $N$. leporinus e $4 \mathrm{~N}$. albiventris para o gene citocromo $b$ e 5 indivíduos de $N$. leporinus e $3 \mathrm{~N}$. albiventris para o gene RAG2. Tais seqüências foram analisadas para estabelecer o espaço de tempo relativo durante o qual a piscivoria evoluiu neste gênero. Os resultados encontrados sugerem que o tempo de divergência entre $N$. leporinus e $N$. albiventris é mais recente do que aquele encontrado para outros gêneros de morcegos. Assumindo taxas de mutações homogêneas entre as linhagens e estimativas para 0 acúmulo de mutações entre 2,6 e 5\% por milhão de anos, os autores propõem um valor 
entre 1.1 e 2.75 m.a. para a divergência das duas espécies. Adicionalmente, sugerem uma origem recente para $N$. leporinus $(0,28-0,7$ m.a.) assim como a parafilia de $N$. albiventris. Contudo, pelo fato da investigação mais profunda de $N$. albiventris não ter sido o objetivo do referido trabalho, haveria necessidade de ampliação na amostragem de indivíduos dessa espécie, envolvendo um maior número de localidades ao longo de toda a sua distribuição geográfica, para que tal resultado fosse confirmado e as relações intraespecíficas deste táxon, esclarecidas. 
INTRODUÇÃO
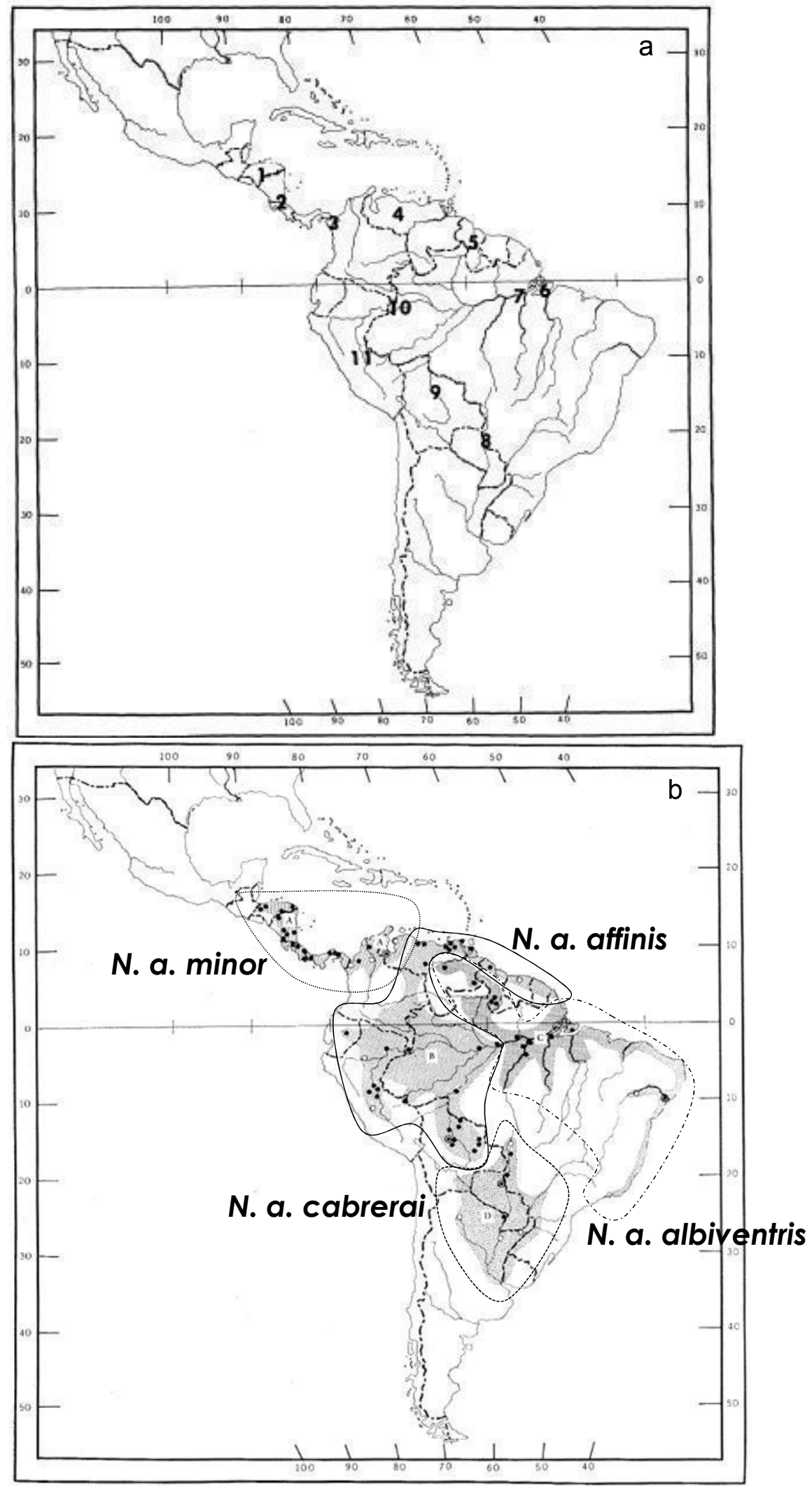

Figura 2. Áreas amostradas por Davis (1976) para analise da variação geográfica em Noctilio albiventris (a) e distribuição geográfica das subespécies propostas (b). A: N. a. minor; B: N. a. affinis; C: N. a. albiventris; D: N. a. cabrerai. Círculos pretos: pontos amostrados; Círculos abertos: registros publicados na literatura. 


\section{OBJETIVOS}

Este trabalho possuiu como objetivo geral a caracterização genética intraespecífica e a determinação do padrão filogeográfico das espécies do gênero Noctilio, usando como marcador molecular o gene mitocondrial citocromo $b$. Para isso, três metas foram definidas:

1. Determinar, através da variabilidade genética destas espécies, a presença ou ausência de estrutura geográfica associada a linhagens mitocondriais.

2. Relacionar os dados genéticos obtidos com aqueles de variação morfológica já descrita para $N$. leporinus e $N$. albiventris ao longo de sua distribuição geográfica.

3. Analisar as relações filogenéticas existentes no gênero e verificar a possível existência de mais de uma linhagem evolutiva dentro da espécie Noctilio albiventris. 


\section{MATERIAL E MÉTODOS}

\section{Material}

Para N. leporinus foram amostrados 63 indivíduos distribuídos por 35 localidades (Figura 3); para N. albiventris foram obtidas amostras de 43 indivíduos, de 19 localidades distintas (Figura 4). As amostras foram obtidas em diferentes centros de pesquisa - Laboratório de Biologia Evolutiva e Conservação de Vertebrados (LABEC-USP); Laboratório de Mastozoologia (UFES); Laboratório de Biologia e Evolução Molecular (LBEM - UFMG); Universidade Federal da Paraíba (UFPB); Museum of Vertebrate Zoology (MVZ), Berkeley, USA; Royal Ontario Museum (ROM), Canadá; Field Museum of Natural History (FMNH), Chicago, USA - e pesquisadores - Ana Carolina Martins, Adalberto Césari, Eliane Gimenez, Katarine Santos e Thieres Pinto. A amostragem foi complementada com uma coleta, realizada no Rio Purus, com o pesquisador Paulo Estefano Bobrowiec, do Instituto Nacional de Pesquisas da Amazônia - INPA. Além disso, as seqüências do gene citocromo $b$ disponíveis no GeneBank para o gênero Noctilio foram incluídas. Uma descrição detalhada das amostras pode ser encontrada no Anexo 1. 


\section{Noctilio leporinus}

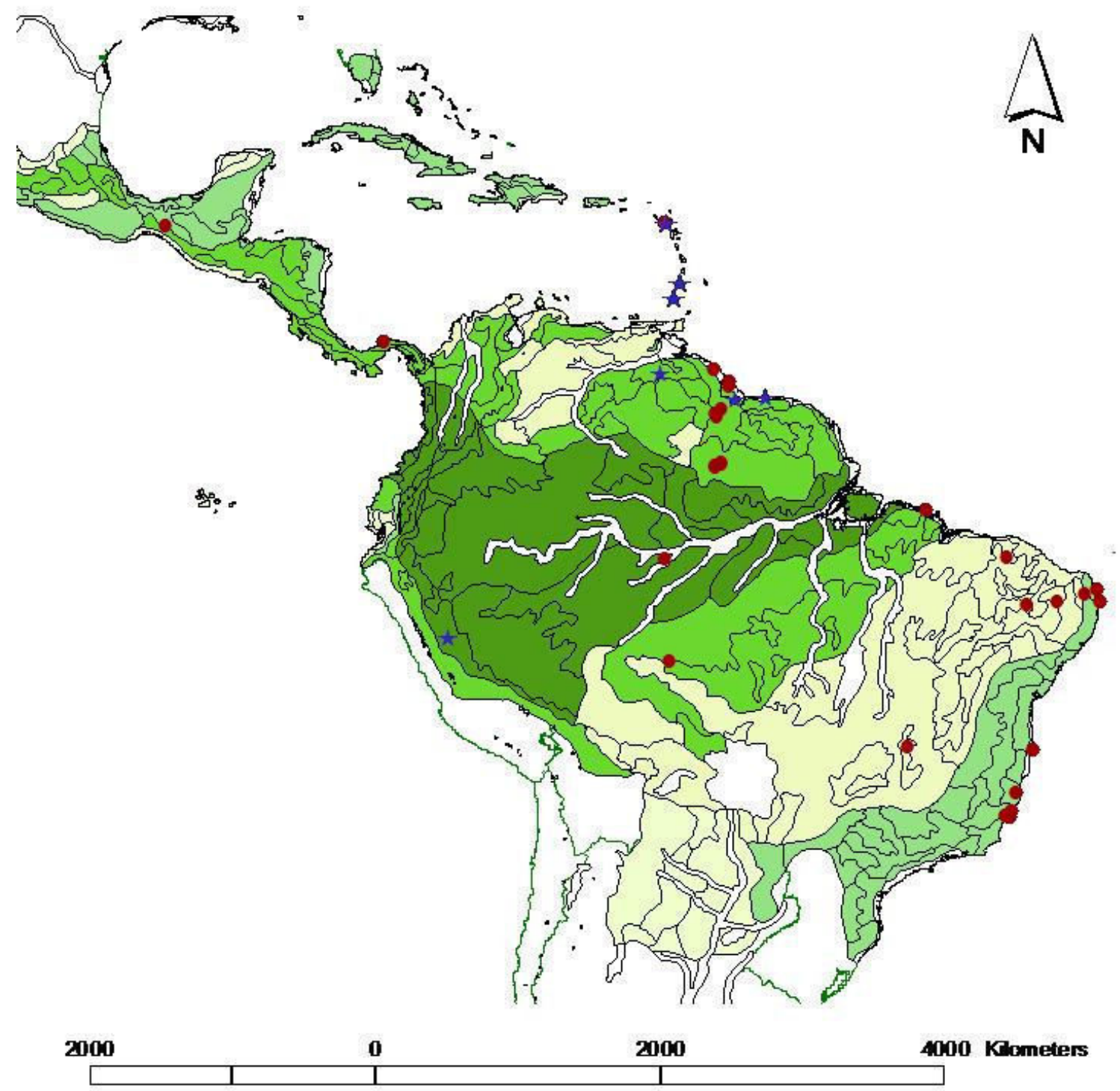

Figura 3. Mapa das localidades amostradas para N. leporinus. Amostras obtidas no decorrer do projeto. $\star$ Seqüências obtidas através do Genebank. 


\section{Noctilio albiventris}

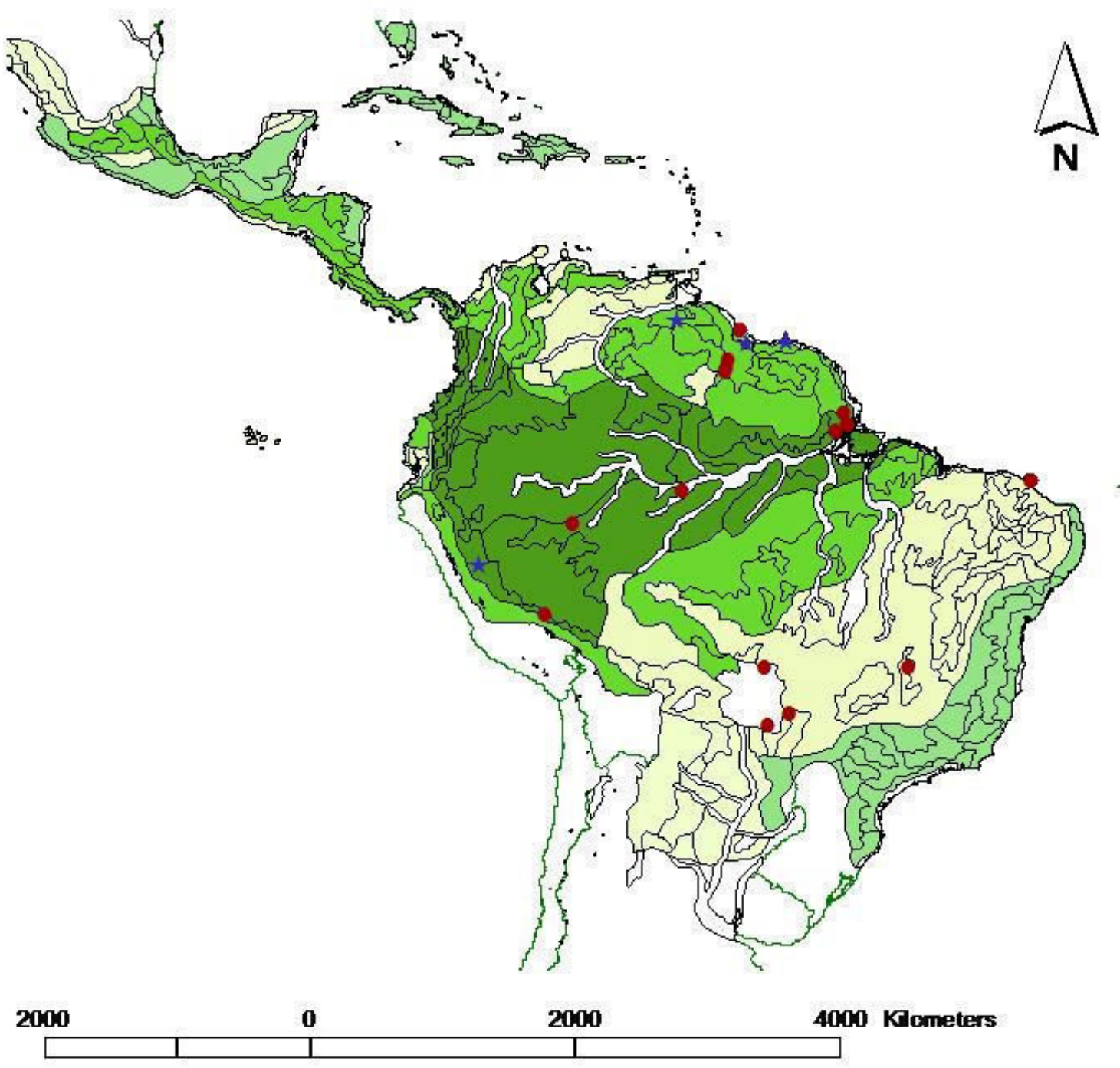

Figura 4. Mapa das localidades amostradas para N. albiventris. $\bullet$ Amostras obtidas no decorrer do projeto.

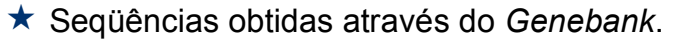




\section{Métodos}

Os morcegos foram capturados através de redes de neblina, utilizando-se luvas de couro para o seu manuseio. As amostras de tecido coletadas (fígado e/ou membrana da asa) foram preservadas em etanol absoluto e mantidas sob refrigeração a $-20^{\circ} \mathrm{C}$ até sua utilização.

\section{Obtenção das seqüências nucleotídicas}

As amostras foram submetidas ao protocolo de extração de DNA com $\mathrm{NaCl} / \mathrm{SDS} /$ Proteinase K (Bruford et al., 1992). Aquelas de quantidade reduzida foram extraídas pelo método fenol-clorofórmio (Sambrook et al., 2001), enquanto outras foram submetidas a um Kit de extração que potencializa a quantidade de DNA obtida a partir de fragmentos mínimos de tecido (CST gDNA mini tissue kit, Invitrogen). Posteriormente, foram amplificadas através do método de Reação em Cadeia da Polimerase (PCR) duas regiões de interesse no DNA mitocondrial: o gene citocromo $b$ e a região controle, ou $d$ loop. Apesar da proposta inicial do projeto consistir somente da análise do gene citocromo $b$, a escolha da utilização de um segundo marcador molecular foi realizada por ser de interesse na confirmação de alguns resultados.

Para a amplificação do gene citocromo $b$ foi utilizado o par de primers (iniciadores) BAT05A e BAT14A, que foram modificados a partir dos primers criados no Museum of Vertebrate Zoology (Berkeley, CA, USA) e originam um fragmento de aproximadamente $1240 \mathrm{pb}$. A região $d$-loop teve sua região hipervariável 1 amplificada (cerca de $450 \mathrm{pb}$ ) através de modificações de primers universais utilizados por Moraes-Barros et al. (2006). As amostras amplificadas foram purificadas com as enzimas Exo I (Exonuclease I) e SAP (Shrimp Alkaline Phosphatase) e as reações de seqüenciamento foram realizadas com o kit ABI Prism BigDye Terminator Cycle Sequencing (Applyed Biosystems), no equipamento a laser ABI PRISM 3100 Genetic Analyser ou, similarmente, com o Kit DyEnamic ET Terminator Cycle Sequencing (GE Healthcare), no equipamento MegaBACE 1000. Para o seqüenciamento do gene citocromo $b$ também foram utilizados primers internos. As seqüências de todos os primers utilizados, tanto para amplificação como para seqüenciamentos das regiões de interesse, encontram-se listadas no Anexo 2. Os 
protocolos e perfis de temperatura adotados para as reações de PCR e purificação estão listados no Anexo 3 e 4, respectivamente. Os protocolos adotados para as reações de seqüenciamento com ambos os kits seguiram as orientações de cada fabricante.

A qualidade das seqüências foi verificada no programa Phred v.0.20425 (Ewing et al., 1998) e os fragmentos seqüenciados foram montados e alinhados no programa Phrap v.0.990319 (Green, 1994), sendo visualizados e editados no programa Consed 12.0 (Gordon et al., 1998). Alinhamentos adicionais e interpretações filogenéticas foram realizados nos programas MEGA4 (Tamura et al., 2007), PAUP*4.0 b10 (Swofford, 2002), Garli 0.951 (Zwickl, 2006) e Mr. Bayes 3.1 (Ronquist et al., 2005) enquanto análises intraespecíficas foram feitas nos programas DNAsp ver4.2 (Rozas et al., 2003) e Arlequin 3.1 (Excoffier et al., 2006). As estimativas coalescentes foram realizadas no software MDIV (Nielsen, 2002).

\section{Análises Filogenéticas e Intraespecíficas}

Foram realizadas análises filogenéticas através dos métodos de distância (Neighborjoining), Máxima Verossimilhança, Máxima Parcimônia e Bayesiano. O melhor modelo evolutivo foi obtido pelo programa Modeltest 3.1 (Posada e Crandall, 1998) para quatro diferentes conjuntos de dados, que foram aplicados para análises distintas. O primeiro grupo incluiu todos os indivíduos do gênero e os grupos externos (análises filogenéticas); o segundo contou somente com as seqüências das espécies de Noctilio (análises interespecíficas); e os outros dois foram formados apenas pelos indivíduos de $N$. leporinus e N. albiventris (análises intraespecíficas e coalescentes).

O método de Neighbor-joining foi implementado no programa MEGA4, utilizando o teste de filogenia de bootstrap, com um total de 1000 replicações. As análises Bayesianas foram realizadas no programa Mr. Bayes 3.1, com um total de 5 milhões de gerações para as cadeias de Markov Monte Carlo (MCMC). A definição da melhor topologia pelo método MCMC baseia-se no algorítmo Metropolis-Hastings para a busca. De acordo com este método, o programa estima a verossimilhança de uma árvore dado um valor inicial de theta 
$(\Theta)$. Na próxima etapa, o programa faz um rearranjo na topologia da árvore e calcula de novo o valor de verossimilhança para esta nova topologia. Tal topologia pode então ser aceita ou rejeitada com base na comparação do seu valor de verossimilhança com relação à topologia anterior, e assim sucessivamente, num processo que cria uma cadeia de Markov. Valores amostrados a partir desta cadeia geram uma curva de valores de verossimilhança, permitindo acessar o melhor valor do parâmetro estimado dada a sua matriz de seqüências, bem como a variância dessa estimativa (Kuhner et al., 1998). A amostragem das cadeias foi realizada a cada 100 gerações, fornecendo o equivalente a 50 mil amostras para a distribuição das probabilidades posteriores. O tempo para o estabelecimento da fase estacionária (burn in time), correspondente a $25 \%$ das amostras obtidas, foi de 12,5 mil amostras. As análises por Máxima Verossimilhança foram executadas no programa Garli 0.951, cujo modelo de implementação é equivalente àquele adotado pelo programa PAUP*, fazendo com que os escores de verossimilhança ( $(\mathrm{nL} L)$ das árvores obtidas sejam diretamente comparáveis. A busca foi determinada pela opção que especifica a utilização de dois parâmetros para 0 encerramento automático ("enforcetermconditions"=1). Se as condições especificadas por esses dois parâmetros são alcançadas antes do número de gerações estipuladas, a busca é finalizada. Isso significa que o programa deixou de encontrar topologias com escores significativamente melhores. Para tais parâmetros, "genthreshfortopoterm" e "scorethreshforterm", os valores atribuídos (respectivamente, 25000 e 0,01) foram superiores ao default do programa. A elevação destes parâmetros pode melhorar os escores obtidos para as topologias, especialmente para um conjunto de dados grande. Para os três métodos de análise filogenética foi adotado o modelo de evolução molecular proposto pelo programa Modeltest 3.1. Por fim, o programa PAUP*4.0 b10A foi utilizado para a construção da filogenia pelo método de Máxima Parcimônia. Foi estabelecida uma busca heurística com adição randômica de seqüências, sendo estipulado um total de 10.000 réplicas. O número de árvores mais parcimoniosas armazenadas na memória do programa foi limitado em no máximo cinco para cada réplica.

A hipótese de taxas mutacionais distintas entre as espécies também foi verificada. Os dois conjuntos de dados foram submetidos ao teste de Tajima - Relative Rate Test (Tajima, 1993) no programa MEGA4. O resultado do teste estatístico não foi significativo para a rejeição da hipótese nula de taxas mutacionais iguais entre as linhagens. Sendo assim, foi 
possível assumir que o gene citocromo b e a região $d$-loop estão sujeitos a taxas evolutivas equivalentes nas duas espécies.

As árvores encontradas nas análises filogenéticas foram comparadas por meio de um teste de topologia no programa PAUP4.0b10. O teste não-paramétrico de Shimodaira-Hasegawa (1999) foi utilizado para comparar simultaneamente os escores das topologias encontradas sob os diferentes métodos de análise filogenética. Esse teste teve como objetivo indicar se as topologias possuíam valores significativamente distintos levando em conta as premissas assumidas por cada método.

Por fim, as análises intraespecíficas - diversidade haplotípica e nucleotídica (respectivamente $\theta_{\Pi}$ e $\theta_{s}$ ), análise de variância molecular (AMOVA), estimativas de fluxo gênico (Fst) e testes de neutralidade - foram realizadas no programa Arlequin 3.1, utilizando os critérios de evolução molecular sugeridos pelo programa Modeltest. $O$ programa DNAsp foi utilizado para a geração das planilhas de entrada do programa Arlequin.

\section{Análises coalescentes e estimativas de tempo}

Estimativas coalescentes para cálculos de tempo de divergência foram realizadas através do programa MDIV. Foi adotado o modelo evolutivo de sítios finitos (HKY), com um total de $5,5 \times 10^{6}$ ciclos de MCMC, sendo os primeiros $5 \times 10^{5}$ ciclos descartados como burn in time. Para cada conjunto de dados foram rodadas 3 análises, repetindo-se os critérios utilizados, a fim de verificar os valores obtidos nas estimativas. Assumindo uma taxa evolutiva para o gene citocromo $b$ de $2,6 \%$ por milhão de anos, o tempo de divergência de cada linhagem pôde ser obtido através da formula:

$$
T_{\text {divergência }}=E[T M R C A] \times \theta / 4
$$


Onde $\mu$ representa a taxa mutacional por ano por gene, ou seja, $2,6 \% \times 10^{6}$ anos $\times 1140$ pares de bases, e E[TMRCA] e $\theta$ são parâmetros fornecidos pelo programa. A partir disso foram realizadas estimativas de tempo para a origem da linhagem de $N$. leporinus e $N$. albiventris, assim como para a origem dos clados encontrados em $N$. albiventris.

Complementarmente, o programa MEGA4 foi utilizado para obtenção do valor de distância em rede $\left(D_{\text {net }}\right)$ entre as seqüências. Tal valor foi aplicado na fórmula:

$$
D_{\text {net }}=2 \mu \mathrm{T}(\text { Edwards e Beerli, 2000) }
$$

para cálculo do tempo de separação entre as duas espécies do gênero (T). Por fim, além da estimativa de tempo para o surgimento da linhagem de $N$. leporinus, o tempo desde a sua expansão também foi calculado, utilizando o valor de $\mathrm{T}$ (Tau), fornecido pelo programa Arlequin, e aplicando na fórmula:

$$
\mathrm{T}_{\text {expansão }}=\frac{\mathrm{T}}{\mu}
$$




\section{RESULTADOS}

Foram obtidas 95 seqüências totalizando 1140 pares de bases do gene citocromo $b$, sendo 56 indivíduos de $N$. leporinus e 39 de $N$. albiventris, às quais foram adicionadas amostras disponibilizadas no GenBank (números de acesso AF330803 a AF330806: N. albiventris; AF330794 a AF330799, AF330802: N. leporinus) do trabalho de Lewis-Oritt et al (2001), totalizando 63 seqüências de $N$. leporinus e 43 de $N$. albiventris. Para a região $d$-loop foram seqüenciados 56 indivíduos de $N$. leporinus e 43 indivíduos de $N$. albiventris, dos quais obteve-se um fragmento de 371 pares de bases. A maioria das seqüências obtidas correspondeu a um haplótipo distinto. Para o gene citocromo $b$ foram encontrados 55 haplótipos e 121 sítios polimórficos em $N$. leporinus, enquanto $N$. albiventris apresentou 41 haplótipos e 186 sítios polimórficos. Para a região $d$-loop 49 haplótipos com 81 sítios polimórficos foram obtidos em $N$. leporinus e 39 haplótipos contendo 98 sítios polimórficos em $N$. albiventris

O conjunto de seqüências apresentou uma heterogeneidade de composição de bases nucleotídicas relevante, indicando a necessidade de determinação de um modelo de evolução molecular para os dados. Assim, o melhor modelo foi determinado para cada um dos conjuntos de dados, assim como para o total de seqüências, incluindo os grupos externos, através do programa Modeltest 3.1. A relação dos modelos utilizados, com as respectivas características para cada um dos conjuntos de dados encontra-se listada na Tabela I. As análises filogenéticas e populacionais foram realizadas seguindo tais modelos. 
Tabela I. Modelos evolutivos sugeridos para cada um dos conjuntos de dados pelo programa Modeltest 3.1. * Baseado em Nei e Kumar (2000).

\begin{tabular}{|c|c|c|c|}
\hline Espécie & Região & Modelo evolutivo & Características* \\
\hline \multirow[t]{2}{*}{ N. leporinus } & $d$-loop & $H K Y+I+G, \alpha=0.7819$ & $\begin{array}{l}\text { Diferentes freqüências para as } \\
\text { bases nucleotídicas; razão ti/tv; } \\
\text { heterogeneidade na taxa de } \\
\text { mutação entre os sítios }(\alpha)\end{array}$ \\
\hline & citocromo $b$ & $\mathrm{HKY}+\mathrm{I}$ & $\begin{array}{l}\text { Diferentes freqüências para as } \\
\text { bases nucleotídicas; razão ti/tv }\end{array}$ \\
\hline \multirow{3}{*}{ N. albiventris } & $d$-loop & $H K Y+I+G, \alpha=0.5453$ & $\begin{array}{l}\text { Diferentes freqüências para as } \\
\text { bases nucleotídicas; razão ti/tv; } \\
\text { heterogeneidade na taxa de } \\
\text { mutação entre os sítios }(\alpha)\end{array}$ \\
\hline & & & \\
\hline & citocromo $b$ & TVM+I+G, $\alpha=0.8682$ & $\begin{array}{l}\text { Diferentes freqüências para as } \\
\text { bases nucleotídicas; diferentes } \\
\text { taxas de substituição entre as } \\
\text { bases; heterogeneidade na taxa de } \\
\text { mutação entre os sítios ( } \alpha \text { ) }\end{array}$ \\
\hline \multirow{2}{*}{$\begin{array}{l}\text { N. leporinus } \\
+ \\
\text { N. albiventris }\end{array}$} & $d$-loop & $H K Y+I+G, \alpha=0.6208$ & $\begin{array}{l}\text { Diferentes freqüências para as } \\
\text { bases nucleotídicas; razão ti/tv; } \\
\text { heterogeneidade na taxa de } \\
\text { mutação entre os sítios }(\alpha)\end{array}$ \\
\hline & citocromo $b$ & TVM+I+G, $\alpha=1.5216$ & $\begin{array}{l}\text { Diferentes freqüências para as } \\
\text { bases nucleotídicas; diferentes } \\
\text { taxas de substituição entre as } \\
\text { bases; heterogeneidade na taxa de } \\
\text { mutação entre os sítios }(\alpha)\end{array}$ \\
\hline $\begin{array}{l}N . \text { leporinus + } \\
N . \text { albiventris + } \\
\text { outgroup }\end{array}$ & citocromo $b$ & TVM+I+G, $\alpha=1.8051$ & $\begin{array}{l}\text { Diferentes freqüências para as } \\
\text { bases nucleotídicas; diferentes } \\
\text { taxas de substituição entre as } \\
\text { bases; heterogeneidade na taxa de } \\
\text { mutação entre os sítios }(\alpha)\end{array}$ \\
\hline
\end{tabular}

\section{Análises Intraespecíficas}

As estimativas para o número médio de diferenças par a par apontaram uma divergência intraespecífica de $0,98 \%$ em $N$. leporinus e $4,72 \%$ em $N$. albiventris, com $5,68 \%$ de divergência entre as duas espécies. As análises intraespecíficas mostraram que $N$. leporinus possui uma diversidade nucleotídica inferior a de $N$. albiventris em ambas as regiões analisadas. Também foi possível observar para esta espécie valores significativos nos dois testes de desvio da neutralidade realizados: D-Tajima (Tajima, 1989) e F-Fu (Fu, 
1997) o que, neste caso, pode ser interpretado como um sinal de rápido crescimento populacional. A Tabela II apresenta um resumo das estimativas populacionais realizadas para as duas espécies. $\mathrm{Na}$ análise de distância par-a-par realizada entre os indivíduos de cada espécie, em $N$. leporinus foram encontrados valores acima da média na comparação entre as amostras do México com as demais (entre 2, 2 e 3,4\%), e valores de até $8 \%$ de divergência entre alguns indivíduos de $N$. albiventris.

Tabela II. Índices de diversidade molecular estimados para as duas regiões do DNAmit em $N$. leporinus e $N$. albiventris. *valores não significativos.

\begin{tabular}{cccccccccc}
\hline \multirow{2}{*}{ Espécie } & \multirow{2}{*}{ Região } & \multicolumn{8}{c}{ Índice de diversidade molecular } \\
\cline { 5 - 11 } & & $\mathrm{N}$ & $\mathrm{h}$ & $\mathrm{H}$ & $\pi$ & $\theta_{\pi}$ & $\theta \mathrm{s}$ & $D$ & $F$ \\
\cline { 5 - 11 } Noctilio leporinus & citocromo $b$ & 63 & 55 & 0.9954 & 0.0117 & 13.30 & 26.52 & -1.76 & -24.34 \\
& $d-l o o p$ & 56 & 49 & 0.9948 & 0.0406 & 14.93 & 17.63 & $-0.53^{*}$ & -24.26 \\
\multirow{2}{*}{ Noctilio albiventris } & citocromo b & 43 & 41 & 0.9978 & 0.0430 & 49.05 & 43.22 & $0.50^{*}$ & -9.41 \\
& $d-l o o p$ & 43 & 39 & 0.9934 & 0.0850 & 31.53 & 22.88 & $1.18^{*}$ & -10.48 \\
\hline
\end{tabular}

O alto valor de diversidade nucleotídica encontrado para $N$. albiventris, principalmente para o gene citocromo $b$, é justificado pelo elevado número de diferenças nucleotidicas nas seqüências de alguns indivíduos. Isso é confirmado ao se analisar a diversidade genética das populações de $N$. albiventris isoladamente. Para tal, a amostragem foi dividida em cinco populações, seguindo como critério de separação sua localização geográfica (Tabela III). Estas foram denominadas Amazônia, Peru, Guianas, Amapá e Pantanal. As localidades em Minas Gerais e Ceará, assim como a seqüência da Venezuela para o gene citocromo $b$ obtida no GeneBank , foram excluídas da divisão, por não se encaixarem em nenhum dos grupos definidos e por não possuírem um $\mathrm{N}$ amostral considerado suficiente para representar uma nova população. A Tabela IV apresenta um resumo das estimativas de diversidade genética realizadas para estes grupos.

A divisão adotada tornou-se interessante para a observação de como a diversidade genética em $N$. albiventris está distribuída. Portanto, ela foi utilizada para a análise de variância molecular (AMOVA) e para estimativas de fluxo gênico (Fst) dentro da espécie. $O$ resultado do teste de AMOVA está apresentado na Tabela $V$ e indica que a maioria da variação genética da espécie está entre as populações determinadas para $N$. albiventris. 
As estimativas de Fst também foram significativas, como apresentado na Tabela VI, sugerindo uma diferenciação entre a maioria das populações.

A Tabela VII apresenta os valores estimados de diferença par-a-par com e sem correção para múltiplas substituições entre as cinco populações definidas para $N$. albiventris, e $N$. leporinus. Excetuando-se os valores entre as populações do Pantanal e Peru, e do Amapá e Guianas, que são agrupadas em um mesmo clado nas análises filogenéticas, as demais distâncias são semelhantes. Essa análise demonstra como os grupos definidos para $N$. albiventris diferem entre si tanto quanto em relação à linhagem de $N$. leporinus. 
Tabela III. Determinação dos grupos em $N$. albiventris conforme localização geográfica das amostras. Algumas localidades foram excluídas da divisão. * localidades das amostras obtidas no GeneBank .

\begin{tabular}{|c|c|}
\hline LOCALIDADE/REGIÃO & POPULAÇÃO \\
\hline \multicolumn{2}{|l|}{ Macapá, AP, Brasil $(n=2)$} \\
\hline Mazagão, AP, Brasil $(n=1)$ & AMAPÁ $(\mathrm{N}=4)$ \\
\hline \multicolumn{2}{|l|}{ Tartarugalzinho, AP, Brasil $(n=1)$} \\
\hline \multicolumn{2}{|l|}{ Rio Juruá, AM, Brasil $(n=1)$} \\
\hline & AMAZÔNIA (N=7) \\
\hline \multicolumn{2}{|l|}{ Rio Purus, AM, Brasil (n=6) } \\
\hline \multicolumn{2}{|l|}{ Annaí, Guiana $(n=1)$} \\
\hline \multicolumn{2}{|l|}{ Karanambo, Guiana $(n=1)$} \\
\hline \multicolumn{2}{|l|}{ Reserva Iwokrama, Guiana $(n=9)$} \\
\hline & GUIANAS $(N=14)$ \\
\hline \multicolumn{2}{|l|}{ Madewini, Guiana $(n=1)$} \\
\hline \multicolumn{2}{|l|}{ *Dubulay Ranch, Guiana $(n=1)$} \\
\hline \multicolumn{2}{|l|}{${ }^{*}$ Marowijne, Suriname $(n=1)$} \\
\hline \multicolumn{2}{|l|}{ Poconé, MT, Brasil $(n=4)$} \\
\hline Pantanal do Rio Negro, MS, Brasil $(n=1)$ & PANTANAL $(\mathrm{N}=9)$ \\
\hline \multicolumn{2}{|l|}{ Miranda, MS, Brasil $(n=4)$} \\
\hline \multicolumn{2}{|l|}{ Maskoitania, Peru $(n=5)$} \\
\hline & PERU $(\mathrm{N}=6)$ \\
\hline \multicolumn{2}{|l|}{ *Leoncio Prado, Peru $(n=1)$} \\
\hline
\end{tabular}


Tabela IV. Estimativas de diversidade molecular para as 5 populações de $N$. albiventris. Para a região $d$-loop as populações tem um tamanho amostral distinto daquele de citocromo $b$.

\begin{tabular}{|c|c|c|c|c|c|c|c|}
\hline \multirow{2}{*}{ Região } & \multirow{2}{*}{ Grupo } & \multicolumn{6}{|c|}{ Índices de diversidade molecular } \\
\hline & & $\mathrm{N}$ & $\mathrm{h}$ & $\mathrm{H}$ & $\pi$ & $\theta_{\pi}$ & $\theta \mathrm{s}$ \\
\hline \multirow{5}{*}{ citocromo b } & Amapá & 4 & 4 & 1.0 & 0.1377 & 25.617 & 19.091 \\
\hline & Guianas & 14 & 12 & 0.98 & 0.3906 & 72.656 & 24.527 \\
\hline & Amazônia & 7 & 7 & 1.0 & 0.0556 & 10.354 & 9.388 \\
\hline & Peru & 6 & 6 & 1.0 & 0.4553 & 84.684 & 31.971 \\
\hline & Pantanal & 9 & 9 & 1.0 & 0.3151 & 58.618 & 34.954 \\
\hline \multirow{5}{*}{$d$-loop } & Amapá & 5 & 5 & 1.0 & 0.0967 & 11.896 & 9.120 \\
\hline & Guianas & 12 & 8 & 0.91 & 0.3487 & 42.892 & 16.226 \\
\hline & Amazônia & 8 & 8 & 1.0 & 0.1785 & 21.954 & 16.198 \\
\hline & Peru & 5 & 5 & 1.0 & 0.4099 & 50.426 & 24.96 \\
\hline & Pantanal & 10 & 10 & 1.0 & 0.1848 & 22.731 & 17.32 \\
\hline
\end{tabular}

Tabela V. Análise de variância molecular em N. albiventris para o gene citocromo b.

Fonte da variação Entre as populações Dentro das populações
Porcentagem
$61.76 \%$
$38.24 \%$

Tabela VI. Estimativas de Fst entre os pares de populações de N. albiventris. Diagonal inferior: Fst; Diagonal superior: $p$-valor. *único valor não significativo.

\begin{tabular}{cccccc}
\hline Fst / p-valor & Amapá & Amazônia & Guianas & Pantanal & Peru \\
\hline Amapá & & 0.000 & 0.027 & 0.018 & 0.018 \\
Amazônia & 0.93008 & & 0.000 & 0.000 & 0.009 \\
Guianas & 0.18504 & 0.60375 & & 0.000 & 0.000 \\
Pantanal & 0.75623 & 0.75797 & 0.66210 & & 0.270 \\
Peru & 0.72617 & 0.64269 & 0.61546 & $0.06234^{*}$ & \\
\hline
\end{tabular}


Tabela VII. Estimativas de distância par a par do gene citocromo $b$ entre as 5 populações definidas em $N$. albiventris e a linhagem de $N$. leporinus. Abaixo da diagonal: Tamura e Nei, $\alpha=1,52$; Acima da diagonal: distância sem correções (distância $p$ ).

\begin{tabular}{ccccccc}
\hline $\begin{array}{c}\text { Distância } \\
\text { par a par }\end{array}$ & N. leporinus & Amapá & Amazônia & Guianas & Pantanal & Peru \\
\hline N. leporinus & & 0,0563 & 0,0432 & 0,0523 & 0,0536 & 0,0509 \\
Amapá & 0,0624 & & 0,0537 & 0,0289 & 0,0568 & 0,0590 \\
Amazônia & 0,0468 & 0,0592 & & 0,0422 & 0,0556 & 0,0400 \\
Guianas & 0,0577 & 0,0311 & 0,0465 & & 0,0553 & 0,0536 \\
Pantanal & 0,0594 & 0,0634 & 0,0616 & 0,0615 & & 0,0292 \\
Peru & 0,0561 & 0,0658 & 0,0440 & 0,0594 & 0,0318 & \\
\hline
\end{tabular}

\section{Análises Filogenéticas}

Os resultados das análises filogenéticas obtidos pelos métodos de distância (Neighborjoining), Máxima Parcimônia, Máxima Verossimilhança e Bayesiano apresentaram topologias semelhantes, apesar de existirem algumas incongruências, que serão apontadas a seguir. Com o intuito de se avaliar a qualidade dos dados, um teste para verificar a presença de saturação foi realizado através do programa DAMBE (Xia e Xie, 2001). Não foi encontrada saturação das substituições nucleotídicas comparando-se o número de transições e transversões com a divergência genética segundo o modelo de Tamura e Nei (1993).

Para as análises filogenéticas com o gene citocromo $b$ foram utilizadas quatro espécies pertencentes à superfamília Noctilionoidea como grupos externos, todas disponibilizadas no GeneBank: Carollia perspicillata, Pteronotus parnellii, Furipterus horrens e Thyroptera tricolor ( $n^{\circ}$ de acesso AF511991, AF338661, AY621004 e AY621005, respectivamente). Para a região $d$-loop, por esta se tratar de uma parte não codificante do DNAmit, a utilização de um grupo externo ficou inviável devido à ocorrência de gaps e de elevada 
divergência nucleotídica entre o gênero Noctilio e seus grupos externos mais próximos filogeneticamente. Dessa maneira, a análise filogenética nesta região restringiu-se apenas aos indivíduos amostrados no trabalho, visto que também não existem seqüências disponíveis da região d-loop para Noctilio no GeneBank .

A Figura 5 representa a árvore encontrada através da análise por Neighbor-joining do gene citocromo $b$ para todas as amostras. Ao se comparar as amostras analisadas com os táxons que compõe o grupo externo, pode-se perceber como o gênero Noctilio é recente, exibindo ramos com comprimentos visivelmente mais curtos. Além disso, a Figura 5 destaca a grande filogenia "em estrela" encontrada para os indivíduos de N. leporinus, característica de espécies que sofreram uma expansão populacional abrupta e recente. Já $N$. albiventris apresenta três clados em todas as análises, com as relações filogenéticas entre os mesmos alterando-se pouco conforme o marcador molecular analisado.

As análises pelos métodos Bayesiano e de Máxima Parcimônia não refletiram a monofilia de $N$. leporinus. Como apresentado pela Figura 6, nestas topologias os indivíduos de $N$. leporinus situam-se em pequenos clados basais ao longo da filogenia, ao invés de serem agrupados em um único clado, como ocorre na análise por Neighbor-joining. Esse resultado é observado tanto para o gene citocromo $b$ quanto para a região $d$-loop, cuja árvore está apresentada no Anexo 5. O resultado da análise por Máxima Verossimilhança foi variável. Inicialmente a topologia encontrada foi muito similar à de Parcimônia e Bayesiana. Entretanto, ao se repetir a análise com o incremento de valores em dois parâmetros (ver métodos), a topologia da Figura 7 foi encontrada. Nela, os indivíduos de $N$. leporinus passaram a ser agrupados em um mesmo clado. $N$. albiventris tornou-se parafilético, mas seus filogrupos permaneceram inalterados, com exceção dos indivíduos que compõem o grupo do Pantanal, onde a relação de monofilia não é mais observada.

A fim de comparar os resultados obtidos nas diferentes análises filogenéticas, as topologias alternativas foram submetidas ao teste SH (Shimodaira e Hasegawa, 1999). Quatro árvores distintas foram comparadas no teste: as provenientes dos resultados da Análise Bayesiana (MB), Máxima Verossimilhança (ML), Neighbor-joining (NJ) e Máxima Parcimônia (MP). O resultado do teste pode ser visualizado na Tabela VIII. Os escores 


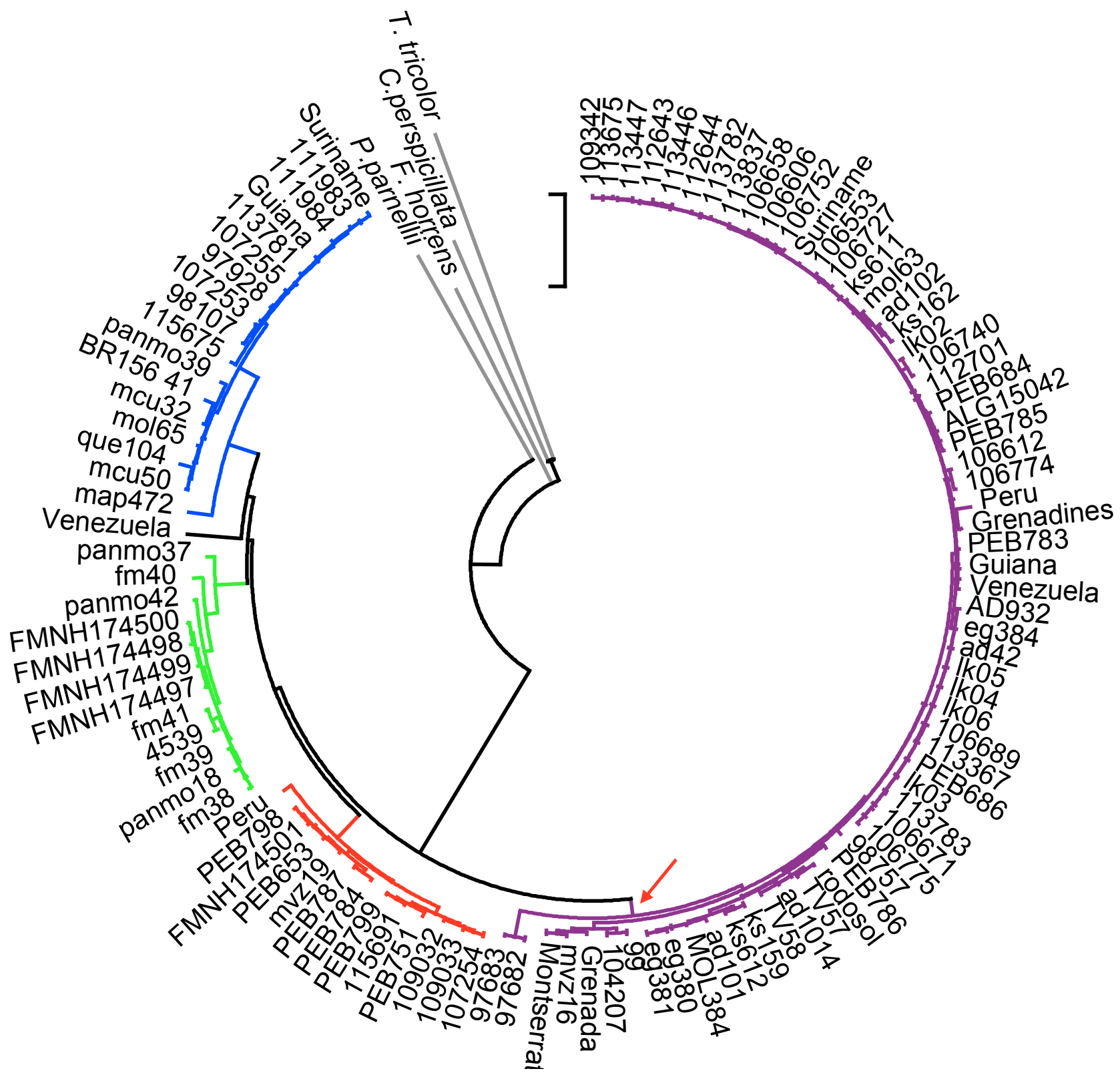

Figura 5. Árvore obtida pela análise por distância (Neighbor-joining) do gene citocromo b em Noctilio. Filogrupos de N. albiventris: Geral = Azul; Pantanal = Verde; Amazônia = Vermelho. $\mathbf{N}$. leporinus = Rosa (nó indicado pela seta). Grupo externo = Cinza. 


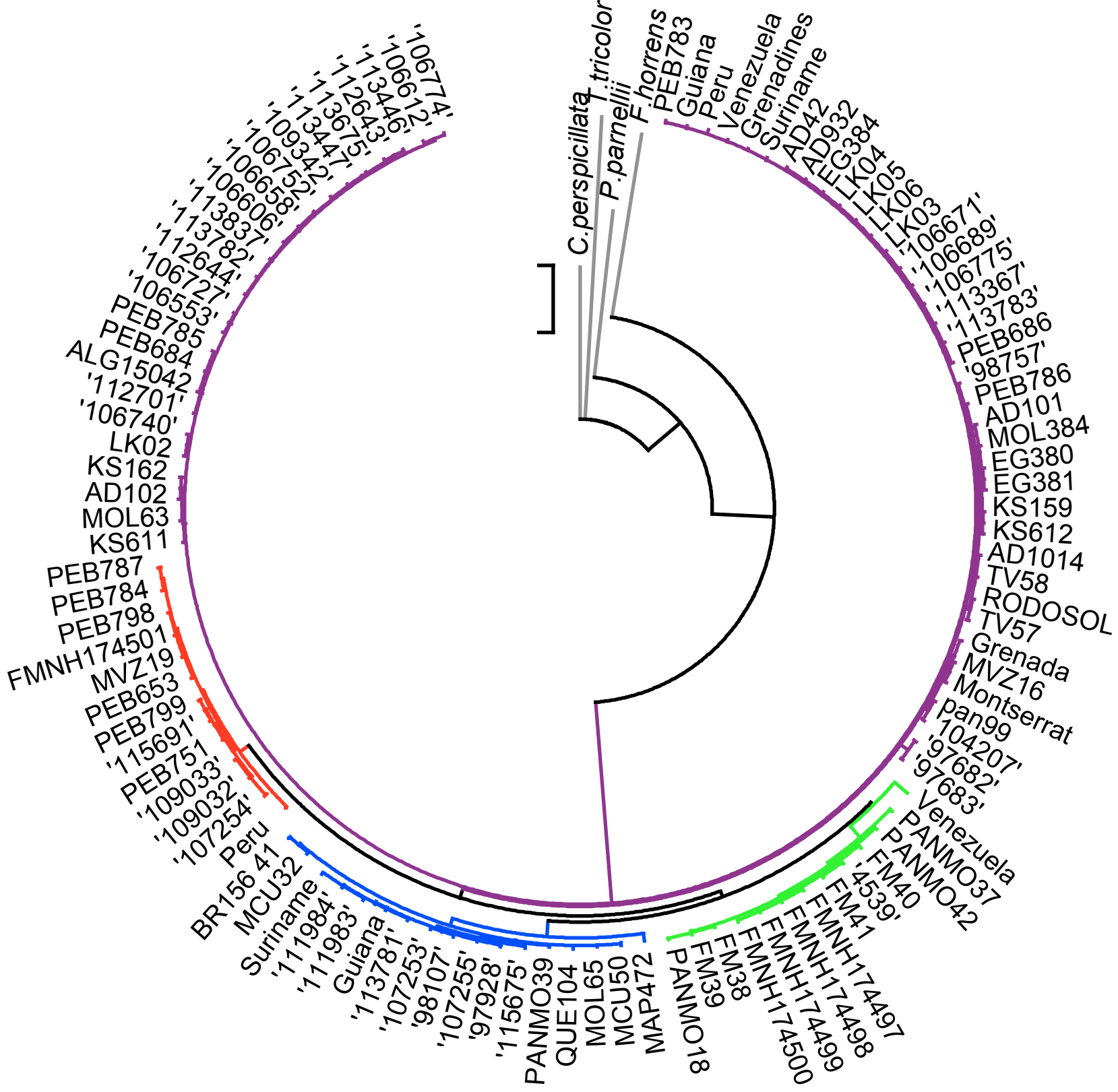

Figura 6. Árvore filogenética encontrada por Análise Bayesiana do gene citocromo b. Filogrupos de $N$. albiventris: Geral = Azul; Pantanal = Verde; Amazônia $=$ Vermelho. N. leporinus $=$ Rosa. Grupo externo $=$ Cinza. 


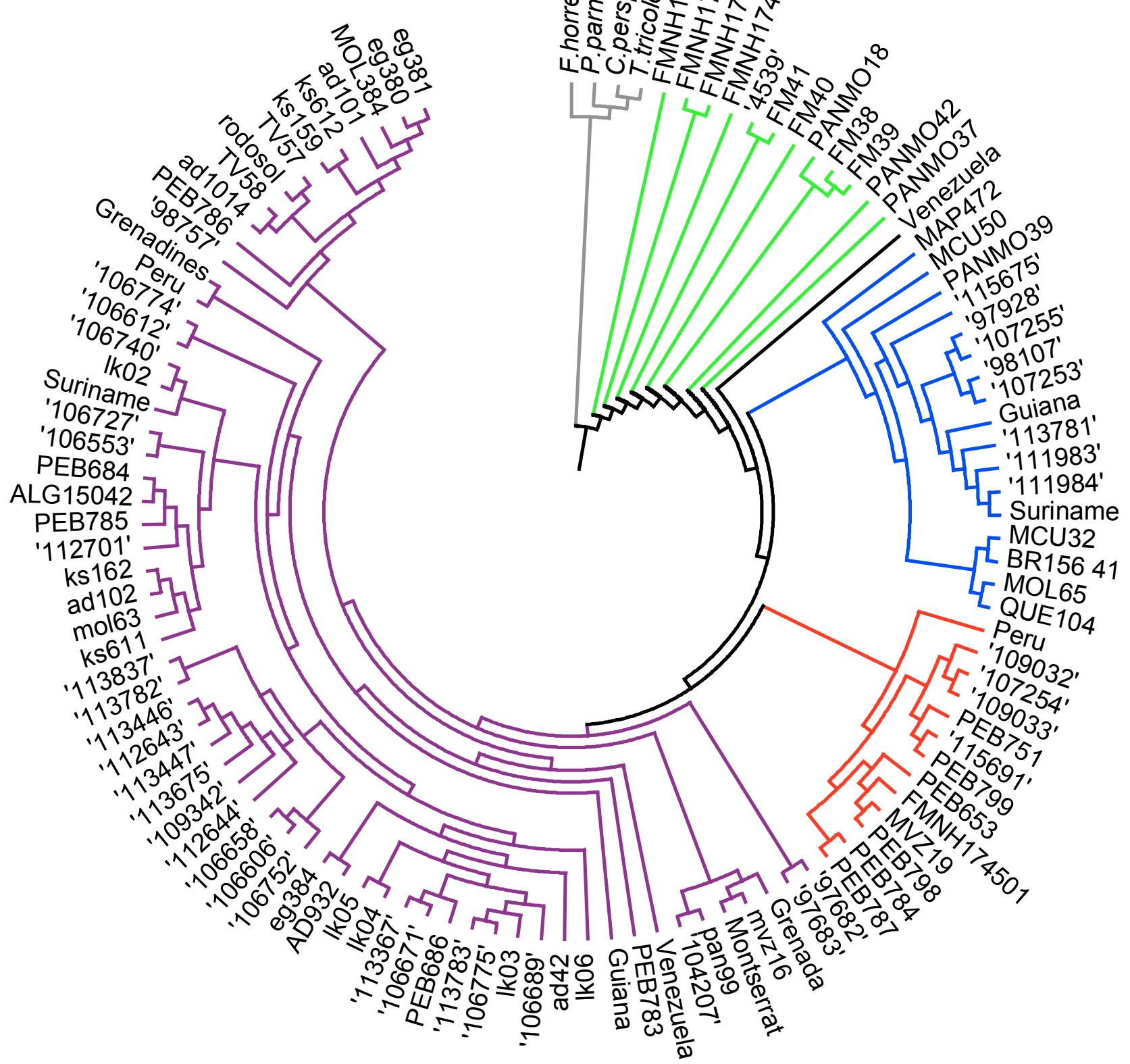

Figura 7. Árvore filogenética obtida por Máxima Verossimilhança do gene citocromo $b$ após o incremento de valores em dois parâmetros da análise. Filogrupos de N. albiventris: Geral = Azul; Pantanal = Verde; Amazônia $=$ Vermelho. $\mathbf{N}$. leporinus $=$ Rosa. Grupo externo $=$ Cinza. 
(valores de verossimilhança) encontrados para todas foram similares. Entretanto, a diferença entre a melhor árvore $(\mathrm{ML})$ e as árvores de NJ e MP foi significativa $(p<0.05)$, sugerindo que as duas últimas não refletem tão bem as relações filogenéticas dentro do táxon. As árvores obtidas pelos critérios de Máxima Verossimilhança e Bayesiana foram consideradas igualmente prováveis dentro das premissas assumidas para cada um dos métodos de análise.

Tabela VIII. Resultado do teste de Shimodaira-Hasegawa na comparação entre as topologias encontradas para os diferentes métodos de análise filogenética. MB=Bayesiana; ML=Máxima Verossimilhança; MP=Máxima Parcimônia; $\mathrm{NJ}=$ Neighbor-joining. * valor significativo.

\begin{tabular}{cccc}
\hline ARVORE & -In L & diferença & $p$-valor \\
\hline MB & 6966,09 & 27,9 & 0,12 \\
ML & 6938,16 & melhor & - \\
NJ & 6975,84 & 37,7 & $0,04^{*}$ \\
MP & 6985,00 & 46,8 & $0,04^{*}$ \\
\hline
\end{tabular}

Aparentemente, os dados obtidos pelos marcadores escolhidos não fornecem informações suficientes para esclarecer completamente as relações dentro do gênero Noctilio. Na tentativa de tornar os dados mais informativos filogeneticamente, uma nova análise foi realizada a partir das seqüências concatenadas dos dois marcadores mitocondriais. Contrariamente aos resultados obtidos pelos marcadores isolados, a análise dos dados concatenados levou à monofilia de $N$. leporinus em todos os métodos. A Figura 8 apresenta a árvore encontrada por Máxima Verossimilhança, enquanto a topologia da análise Bayesiana pode ser vista no Anexo 6. Esse resultado fortalece a adoção das análises filogenéticas que apontam N. leporinus como um grupo monofilético. Além disso, sugere que a análise de um único marcador molecular não é suficiente para esclarecer as relações filogenéticas dentro do gênero. 


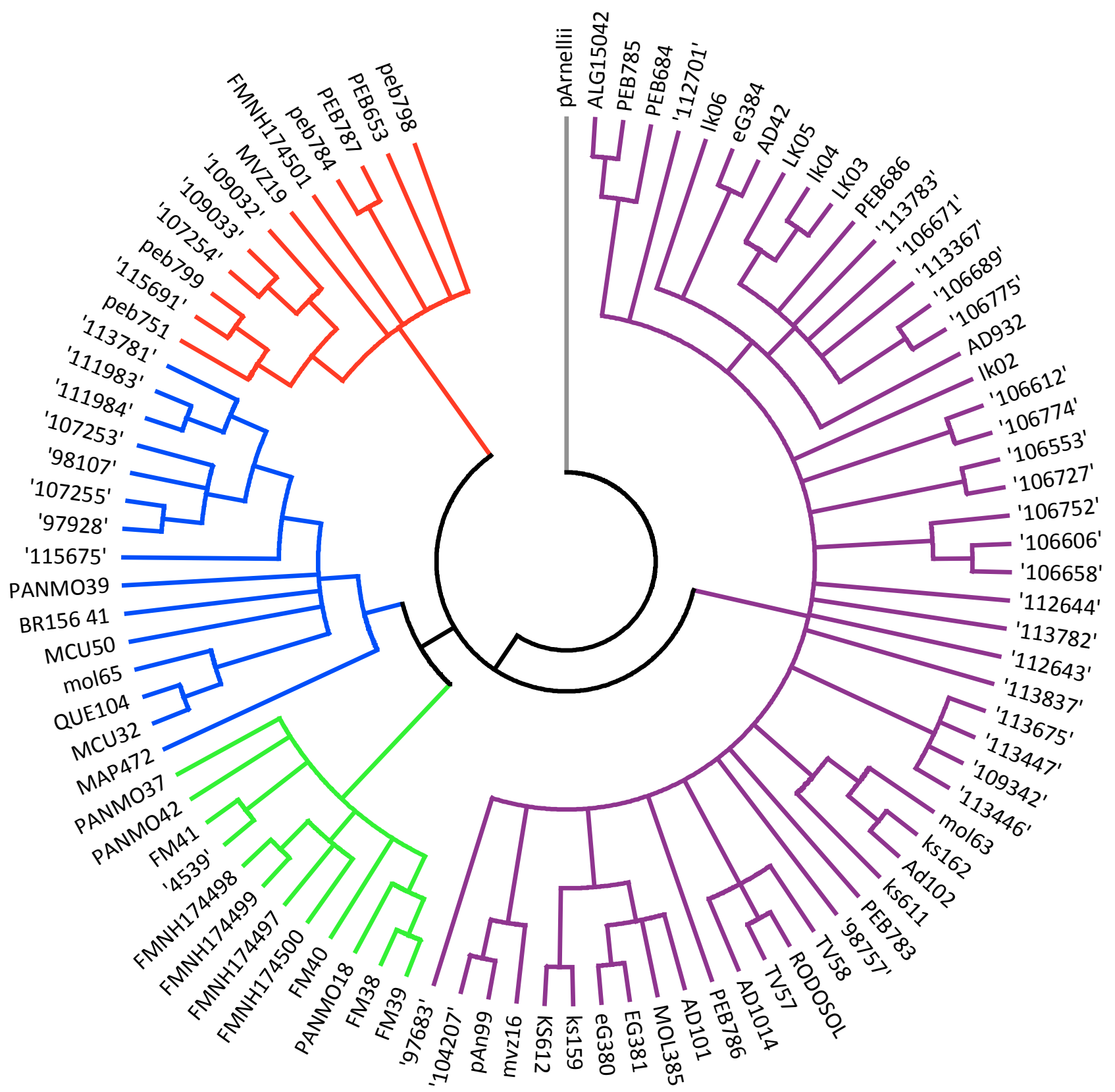

Figura 8. Topologia do consenso obtida a partir da análise por Máxima Verossimilhança (100 réplicas de bootstrap) dos dados concatenados. Filogrupos de N. albiventris: Geral = Azul; Pantanal = Verde; Amazônia = Vermelho. $\boldsymbol{N}$. leporinus $=$ Rosa. Grupo externo $=$ Cinza. 
Assumindo que $N$. leporinus constitui um grupo monofilético, alguns dados podem ser interpretados a partir do resultado da análise por distância. A Figura 9 apresenta a topologia simplificada obtida pela análise filogenética (Neighbor-joining) realizada para todos os indivíduos da amostragem. N. leporinus apresenta uma baixa estruturação genética, possuindo clados onde é possível fazer uma correlação geográfica apenas na América Central. O ramo "América do Sul" representa todos os indivíduos do continente, onde não foi observada nenhuma associação explícita entre filogenia e geografia. Pelo contrário, as relações filogenéticas encontradas para as amostras do continente sul-americano foram inconclusivas, devido à grande semelhança existente entre haplótipos de localidades muito distantes geograficamente e à conseqüente formação de inúmeras politomias na árvore. Uma visualização em detalhes das relações filogenéticas encontradas entre os indivíduos de $N$. leporinus pode ser encontrada no Anexo 7, onde está o consenso de maioria (bootstrap acima de $80 \%$ ) obtido para a análise filogenética por Neighbor-joining para todos os indivíduos da amostragem.

Em N. albiventris foram encontrados três clados com alto suporte, igualmente distantes do clado que agrupa os indivíduos de $N$. leporinus. Estes clados, identificados conforme a Figura 10, são compostos sempre pelos mesmos indivíduos, em todos os métodos de análise filogenética realizados. A Tabela IX apresenta os valores de divergência genética encontrados entre eles e $N$. leporinus. Os valores nela apresentados mostram como as linhagens de $N$. albiventris diferem tanto entre si quanto da outra espécie do gênero. O suporte encontrado para a relação destas três linhagens com aquela de $N$. leporinus, entretanto, varia conforme o marcador analisado.

O fato dos indivíduos de $N$. albiventris não se encontrarem agrupados em um único clado monofilético já foi ressaltado por Lewis-Oritt et al. (2001). Os autores destacaram a parafilia de N. albiventris devido à posição de um espécime proveniente do Peru nas análises filogenéticas. Os resultados atuais corroboram tal separação, além de evidenciarem níveis de divergência filogenética mais significativos dentro deste táxon do que poderia ser alcançado pelo estudo anterior. É importante ressaltar que neste trabalho foram obtidas topologias semelhantes nas análises filogenéticas para os genes citocromo b e RAG2, apesar da análise do gene nuclear não deixar esclarecida a existência de parafilia em $N$. albiventris devido à inclusão de apenas três indivíduos. 


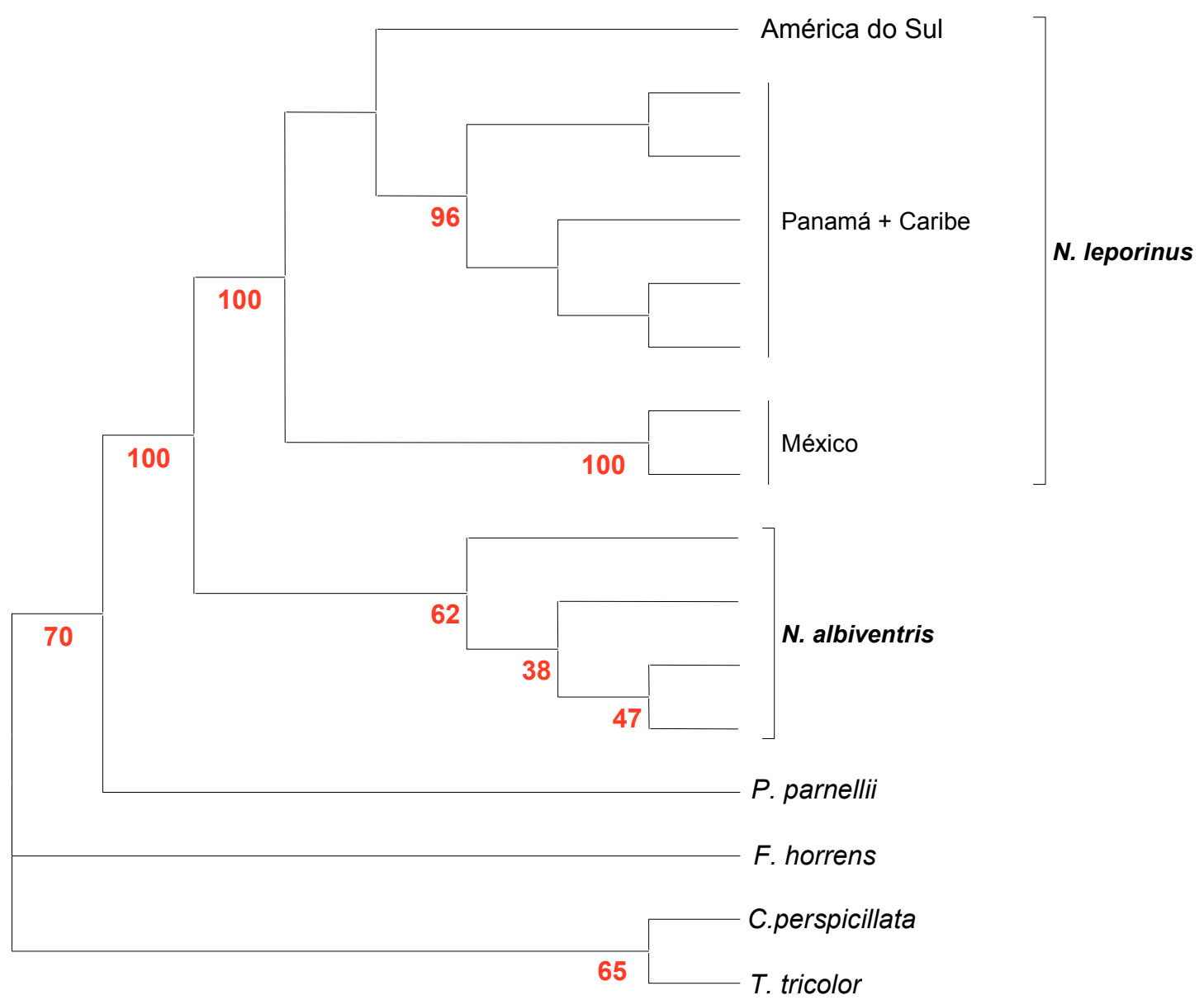

Figura 9. Resultado simplificado da análise filogenética por distância (Neighbor-joining) obtida para todos os indivíduos amostrados, destacando os haplótipos basais encontrados em $N$. leporinus. A árvore completa encontra-se no Anexo 7.

Tabela IX. Estimativas de distância par a par do gene citocromo $b$ entre as linhagens evolutivas encontradas dentro do gênero Noctilio. Abaixo da diagonal: Tamura e Nei, $\alpha=1,52$; Acima da diagonal: distância sem correções (distância p).

\begin{tabular}{ccccc}
\hline Distância & N. leporinus & Pantanal & Amazônia & Geral \\
\hline N. leporinus & & 0.0539 & 0.0430 & 0.0564 \\
Pantanal & 0.0597 & & 0.0555 & 0.0613 \\
Amazônia & 0.0466 & 0.0615 & & 0.0553 \\
Geral & 0.0625 & 0.0684 & 0.0611 & \\
\hline
\end{tabular}


A Figura 10a destaca o resultado da análise por Neighbor-joining do gene citocromo $b$ enquanto a Figura 10b apresenta o resultado obtido com a região $d$-loop. Apesar de não ocorrer uma correlação geográfica estrita das amostras em cada clado, é possível fazer uma associação. Existe um clado composto predominantemente por indivíduos do Pantanal e Peru (clado Pantanal) e outro com indivíduos do bioma amazônico (clado Amazônia). O terceiro clado, mais amplo, está dividido em dois pequenos grupos e abrange biomas distintos, desde a Guiana, passando pelo Maranhão, Nordeste brasileiro e Minas Gerais (clado Geral). As relações filogenéticas resultantes da análise da região $d$ loop apontam que as linhagens do clado do Pantanal e do clado Geral apresentam relações mais estreitas, formando um grupo monofilético, o que é confirmado pela análise bayesiana (Anexo 5). Já a posição do clado amazônico não é conclusiva, sendo observada uma politomia basal em Noctilio.

Com o intuito de confirmar as topologias encontradas para os dois marcadores do DNA mitocondrial, alguns indivíduos da amostragem foram selecionados para a análise do gene nuclear RAG2. Dessa maneira, 27 indivíduos foram seqüenciados e analisados para um total de 708 pares de bases do gene. Por ser tratar de uma região mais conservada do DNA, caracterizada por uma taxa mutacional menor, foram encontrados pouquíssimos sítios polimórficos na amostra. Sendo assim, a análise filogenética apresentou muitas politomias, pois a maioria dos indivíduos possuía o mesmo haplótipo. Conseqüentemente, nenhuma interpretação adicional pôde ser realizada a partir da análise deste marcador nuclear, sendo necessária a análise de mais indivíduos e/ou maior fragmento deste gene. 


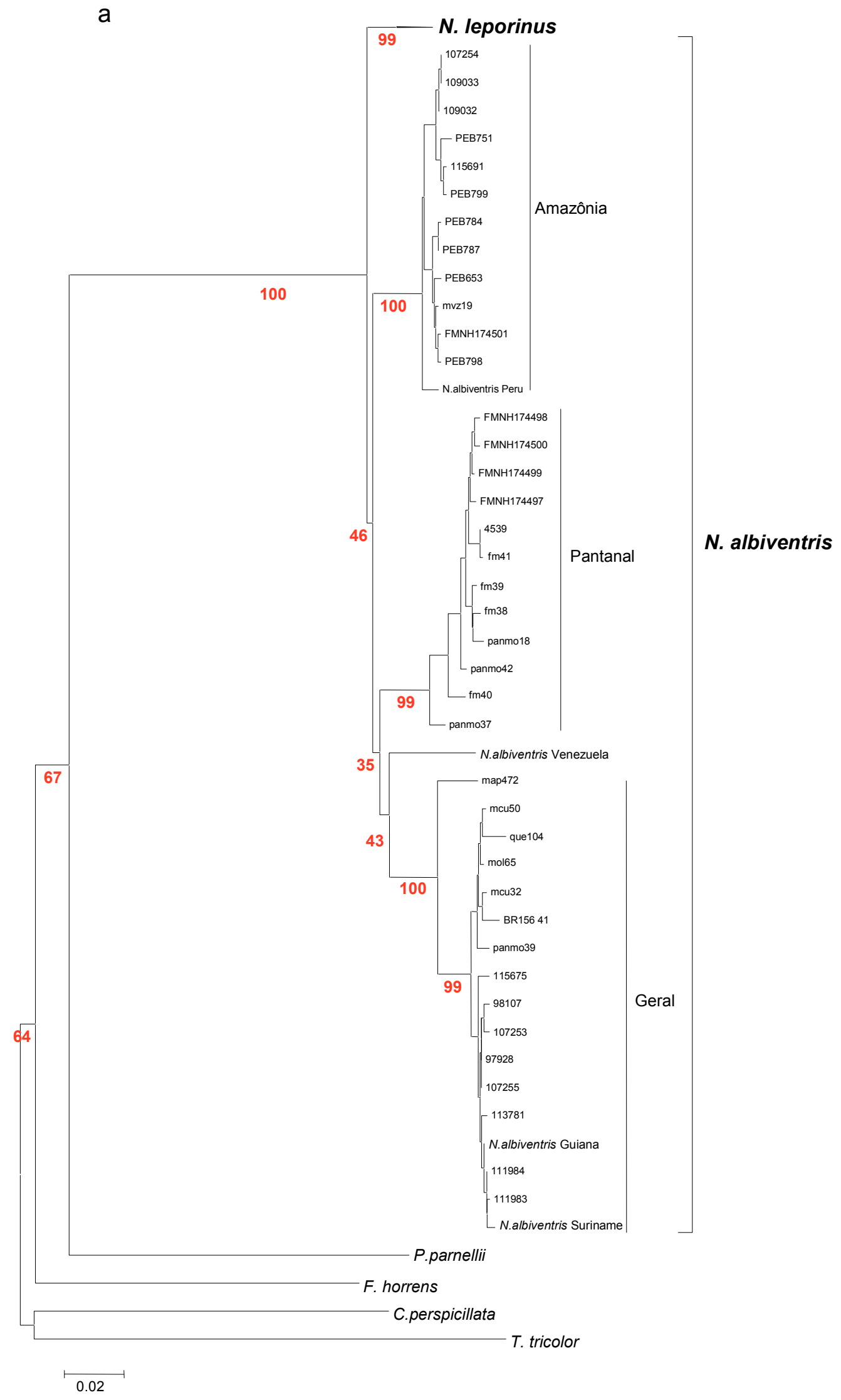


b

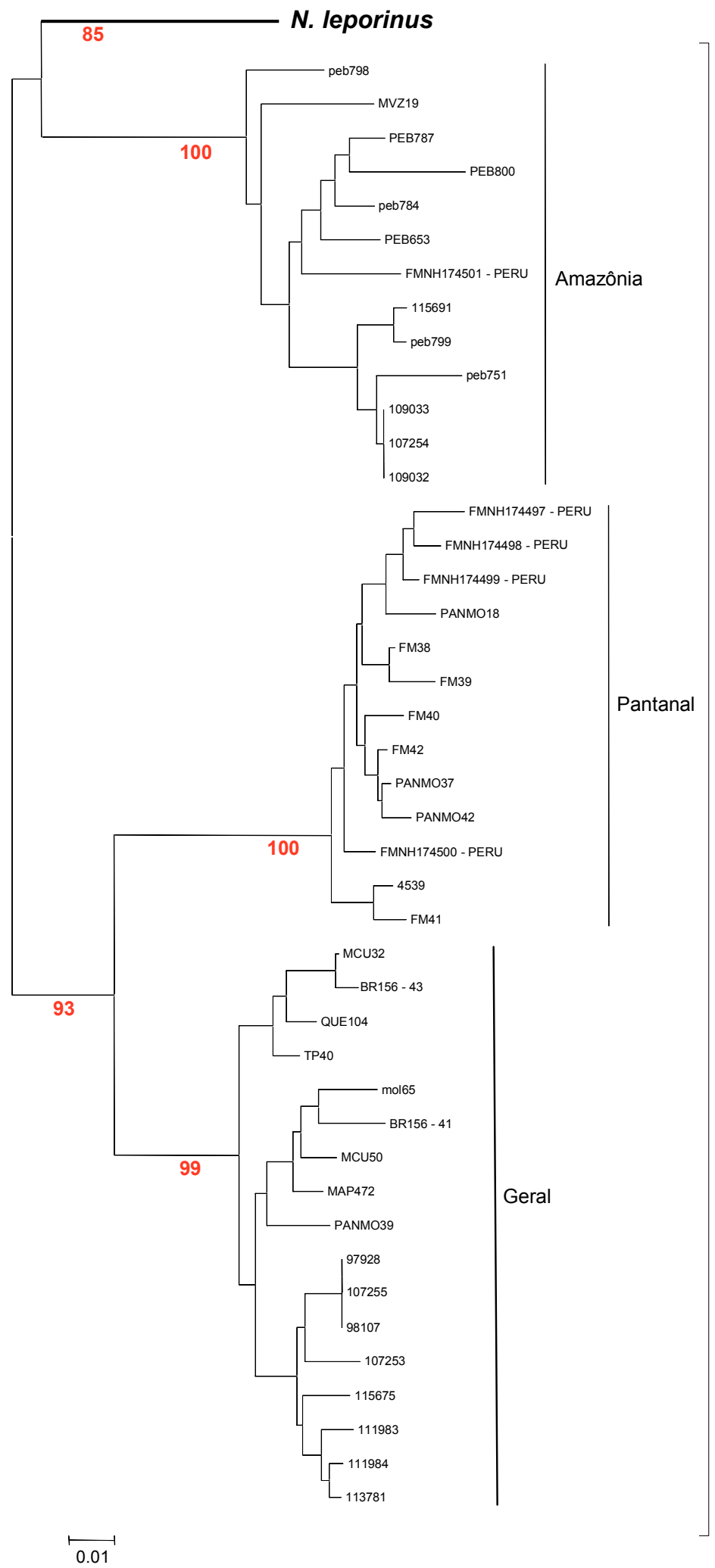

N. albiventris

Figura 10. Análise filogenética por distância (Neighbor-joining) do gene citocromo $b$ (a) e da região $d$-loop (b) mostrando as linhagens de $N$. albiventris. Um dos clados é composto por indivíduos do bioma amazônico; o segundo corresponde a indivíduos do Pantanal; e o terceiro compreende Amazônia, Pantanal e Cerrado. 


\section{Estimativas para o tempo de divergência}

Uma estimativa para a separação entre $N$. leporinus e $N$. albiventris já foi realizada anteriormente. Lewis-Oritt et al. (2001) sugeriram que o tempo de divergência entre $N$. leporinus e $N$. albiventris estaria entre 1.1 e 2.75 milhões de anos atrás, com o ancestral comum mais recente (ACMR) de $N$. leporinus tendo vivido há 280-700 mil anos e o ACMR de $N$. albiventris há 0.98-2.45 milhões de anos. Tal estimativa se baseou no modelo de relógio molecular, assumindo taxas evolutivas constantes entre as linhagens e homogêneas ao longo do marcador molecular utilizado. Para o cálculo das idades das linhagens os autores adotaram as taxas mutacionais para o gene citocromo $b$ entre 2,6 e $5 \%$ por milhão de anos, utilizadas inicialmente para pequenos mamíferos terrestres da Região Neotropical e usualmente utilizadas para morcegos (Hoffmann et al., 2003).

A fim de se confirmar os valores previamente descritos, as estimativas dos tempos de divergência para a linhagem de $N$. leporinus e do ancestral das linhagens de $N$. albiventris foram realizadas através de análises coalescentes. O cálculo do Ancestral Comum Mais Recente (ACMR) em ambas as espécies foi realizado utilizando-se o programa MDIV (Nielsen, 2002), que estima valores para a diversidade populacional (theta - $\theta$ ) e o tempo do ancestral (E[TMRCA]). A Tabela X lista os parâmetros estimados pelo MDIV para cada população analisada, assim como os valores de tempo obtidos para cada uma das linhagens.

Os valores encontrados para o surgimento do ACMR da linhagem de $N$. leporinus, assim como para $N$. albiventris, são muito recentes, remetendo ao Pleistoceno tardio. As estimativas de tempo corroboram as demais análises ao apontar uma origem mais recente para $N$. leporinus em relação a $N$. albiventris. Comparando-se com os valores sugeridos anteriormente, verifica-se uma redução significativa na idade das linhagens, sendo importante relembrar que foi utilizado o valor mínimo das taxas evolutivas usualmente adotadas para este gene mitocondrial (2,6\% por milhão de anos). A adoção da taxa mais baixa significa que os tempos obtidos foram os maiores possíveis para tais estimativas. 
Tabela X. Parâmetros obtidos pelo programa MDIV e valores dos tempos de ACMR das duas espécies, assim como das três linhagens de $N$. albiventris, segundo a fórmula descrita anteriormente (ver Materiais e Métodos).

\begin{tabular}{cccc}
\hline POPULAÇÃo & $\boldsymbol{\theta}$ & E[TMRCA & $\mathbf{T}_{\text {diverg }}$ \\
\hline N. leporinus & 43,3372 & 0,7144 & 261.134 anos \\
N albiventris & 57,6336 & 1,4331 & 696.649 anos \\
Pantanal & 16,5225 & 1,1027 & 153.672 anos \\
Amazônia & 8,7702 & 1,8224 & 134.814 anos \\
Geral & 15,5984 & 2,1631 & 284.589 anos \\
\hline
\end{tabular}

O tempo de separação $(\mathrm{T})$ entre $N$. leporinus e $N$. albiventris também foi estimado seguindo a metodologia adotada por Edwards e Beerli (2000). É importante ressaltar que o tempo T não equivale ao tempo do ACMR entre as espécies. O valor estimado pelo MDIV equivale à época de divergência alélica, que corresponde ao surgimento de um polimorfismo ainda na população ancestral. $O$ tempo $T$ representa a divergência da população ancestral de organismos e é geralmente menor, tendo ocorrido algum tempo depois da divergência genética. A partir do valor de $D_{\text {net }}$ obtido no programa MEGA4 para o conjunto de seqüências de Noctilio, foi encontrado que o tempo de separação entre as duas espécies ocorreu há 538.461 anos. Como visto as seqüências amostradas de $N$. albiventris coalescem há, aproximadamente, 700 mil anos. Já o ACMR dos indivíduos amostrados de $N$. leporinus ocorreu há aproximadamente 260 mil anos. As estimativas sugerem que o ACMR de $N$. albiventris é anterior à origem das duas espécies. Isso indica que a diversidade observada nesta espécie é antiga, e remete a um período anterior à separação com N. leporinus.

O tempo encontrado para a coalescência de todas as seqüências analisadas de $N$. leporinus correspondeu há aproximadamente 260 mil anos. Após seu surgimento, presume-se que a espécie tenha sofrido uma forte expansão geográfica e populacional, o que está refletido nos resultados dos testes de neutralidade. Tendo como base a matriz de dados do gene citocromo $b$, o valor de Tau (T) fornecido pelo programa Arlequin foi utilizado para se calcular o tempo decorrido desde a expansão em $N$. leporinus. Dado o valor $\mathrm{T}=6.127$, foi encontrado o tempo de 103.356,95 anos para o evento. Essa seria a idade, portanto, da expansão de N. leporinus na América do Sul. 


\section{DISCUSSÃO}

\section{Filogeografia de Noctilio leporinus}

Apesar dos trabalhos que incluem a filogenia do gênero Noctilio sempre apresentarem as duas espécies como monofiléticas (Teeling et al., 2005; Jones et al., 2005), essa relação não ficou clara entre as amostras analisadas. As análises filogenéticas sempre confirmam a divisão de $N$. albiventris em três filogrupos, mas a monofilia destes em relação à $N$. leporinus é questionável. O próprio agrupamento das amostras de $N$. leporinus em um único clado não foi bem suportada, pois os métodos Bayesiano e de Máxima Parcimônia não refletiram tal relação.

Entretanto, não existem evidências genéticas nem morfológicas que justifiquem uma possível divisão de $N$. leporinus. Apesar das análises filogenéticas com os marcadores isolados não terem sido totalmente congruentes, o teste de topologia e a análise concatenada dos dados são esclarecedoras quanto às relações filogenéticas desses indivíduos. Os resultados encontrados sugerem que a espécie divergiu recentemente, e sofreu uma grande expansão demográfica em seguida. Assim, a politomia basal encontrada em algumas das filogenias talvez seja reflexo deste evento, onde o processo de expansão sobressalta-se à reciprocidade monofilética dos indivíduos da amostra.

A origem recente desta espécie é evidenciada por muitos fatores. A filogenia em estrela obtida nos resultados das análises filogenéticas, com clados extremamente rasos e sem estruturação geográfica na maior parte da distribuição da espécie; os testes de desvio da neutralidade - D de Tajima e F de $\mathrm{Fu}$, cujos resultados sugerem uma expansão populacional recente; e as estimativas populacionais, que apontam $N$. leporinus como um grupo geneticamente homogêneo, com haplótipos diferindo, em média, apenas 1\%. Com as estimativas coalescentes para o tempo de divergência, porém, a evidência torna-se irrefutável. As datas encontradas para os ancestrais das linhagens do gênero apóiam fortemente a hipótese de uma origem mais recente de $N$. leporinus em relação a $N$. albiventris. 
Como já mencionado, em $N$. leporinus foi encontrada uma pequena estruturação geográfica: um clado basal composto pelos indivíduos do México; um segundo clado reunindo a América Central (Panamá) e llhas Caribenhas; e um terceiro abrangendo todas as localidades amostradas na América do Sul. A ausência de estruturação geográfica entre as localidades da América do Sul sugere uma colonização recente, indicando que a espécie, posteriormente à sua origem, sofreu rápida expansão demográfica no continente Sul-americano. A existência de haplótipos muito semelhantes, que diferem em apenas um par de bases, entre localidades muito distantes geograficamente, como Espírito Santo, Paraíba e Guiana, fortalece essa hipótese. Paralelamente, a existência de haplótipos basais no México, Panamá e Caribe seria uma evidência de que o surgimento da linhagem piscívora de Noctilio tenha ocorrido na América Central.

Sobrepondo-se os resultados encontrados com os de variação morfológica descritos por Davis (1973), observa-se uma correlação dos dados para a região da América Central. Davis propôs para essa população, se estendendo desde o México (costa sul pacífica e atlântica) até o norte da América do Sul (Equador, Colômbia e Venezuela), além das ilhas caribenhas, o nome N. I. mastivus. Apesar de não significativa, o autor destaca ter encontrado uma leve diferença entre os indivíduos das localidades continentais e insulares. Nas análises filogenéticas (Fig. 9) foi observado um clado, contendo haplótipos basais, formado pelos dois indivíduos de Chiapas, no México; um segundo clado foi formado pelas demais amostras da América Central: Panamá e llhas do Caribe. Estes indivíduos podem representar o agrupamento que recebeu o nome de mastivus.

Adicionalmente, a subespécie N. I. leporinus foi proposta para os representantes da Bacia Amazônica, que segregaram nas análises por possuírem os menores tamanhos. Tal distribuição também incluiu a costa brasileira, apesar da mesma ter se baseado em registros publicados na literatura. As análises filogenéticas não demonstraram uma relação de monofilia entre os indivíduos amazônicos, assim como as amostras da costa brasileira, desde o Espírito Santo até o Ceará, também não apresentaram uma estruturação geográfica evidente da sua diversidade genética, o que corrobora a distribuição proposta para esta subespécie. Dentre os poucos clados encontrados com um suporte significativo em N. leporinus, um correspondeu ao agrupamento de localidades do Espírito Santo e 
outro de localidades do Nordeste brasileiro, porém estes não abrangem todos os indivíduos da amostra.

Para a população da região da Bacia do Rio Paraná: leste da Bolívia, Argentina, Paraguai e sul do Brasil, o autor não encontra evidências morfológicas que a distinguam de $N$. $I$. mastivus, exceto sua cor mais clara e o fato das duas estarem separadas por $N$. I. leporinus. Dessa maneira, foi proposta uma terceira subespécie para a região: $N$. $I$. rufescens. Infelizmente não foram amostrados indivíduos das localidades que representariam o grupo rufescens, impossibilitando uma comparação com o trabalho de variação morfológica.

Os dados não possibilitam a verificação de estruturação genética que corrobore a existência das duas subespécies propostas para o continente Sul-americano. Eles apenas permitem inferir que os indivíduos do México possuem haplótipos basais em relação ao restante da distribuição da espécie. Aliado a isto, os únicos registros fósseis para $N$. leporinus são encontrados em Cuba e Porto Rico, e datam do Pleistoceno (Martin, 1972). Tais fatos podem indicar que a linhagem que deu origem a $N$. leporinus tenha surgido na América Central e posteriormente ocupado o restante da América Latina. Essa ocupação teria ocorrido de maneira abrupta, tendo a espécie sofrido uma grande expansão demográfica, favorecida pelo novo nicho ecológico que passou a ocupar. Assim, a ausência de estruturação geográfica na América do Sul é um indicativo desta chegada recente e a rápida expansão populacional justifica a ausência de correlação entre localidades geográficas e haplótipos mitocondriais.

\section{Filogeografia de Noctilio albiventris}

As relações entre a linhagem de $N$. leporinus e aquelas de $N$. albiventris não puderam ser bem estabelecidas. A análise das relações filogenéticas para o gene citocromo $b$ permite apenas a conclusão da existência de três linhagens evolutivas em $N$. albiventris. A análise da região $d$-loop produz a mesma topologia, independente do método filogenético utilizado. Entretanto, possivelmente por apresentar uma taxa mutacional mais elevada, fornece clados menos rasos e com maior suporte filogenético, dando maior resolução às relações de parentesco. Como visto, algumas filogenias apontam para uma maior proximidade filogenética entre os clados do Pantanal e Geral, enquanto a posição do grupo de amostras 
da Alta Bacia Amazônica permanece em uma politomia. Esse resultado também é suportado pela análise dos dados concatenados, apesar do suporte filogenético não ser elevado.

O padrão filogeográfico exibido por $N$. albiventris demonstra que a espécie apresenta três linhagens evolutivas majoritariamente associadas a regiões geográficas distintas, porém com certa sobreposição de ocorrência. As análises coalescentes apontam que a linhagem de $N$. albiventris composta por algumas amostras da Guiana, Baixa Bacia Amazônica e localidades de outros biomas brasileiros (clado Geral) possui seu ACMR há aproximadamente 285 mil anos. Já os clados Amazônia e Pantanal, respectivamente formados por amostras da Alta Bacia Amazônica e do Pantanal Matogrossense, com uma sobreposição de ocorrência na Amazônia peruana, possuem idades de diversificação mais recentes (respectivamente 135 e 153 mil anos). O clado Geral, portanto, é mais antigo. A maior extensão geográfica por ele ocupada pode ser reflexo da sua idade. Indivíduos pertencentes a esta linhagem são encontrados nas Guianas, Amapá, Ceará, Minas Gerais e Pantanal, incluindo as áreas de ocorrência dos outros dois clados. Tal amplitude pode sugerir uma ancestralidade desta linhagem em relação às demais. As zonas de sobreposição observadas podem ser resultado de contato secundário, conseqüentes de eventos de vicariância que isolaram duas populações em algum período no passado, originando linhagens distintas que tornaram a se encontrar posteriormente. Assim, é possível propor que a linhagem mais antiga deu origem de maneira independente às duas linhagens mais recentes, uma no Pantanal e outra na Bacia Amazônica. Alternativamente, algum evento passado pode ter provocado a fragmentação da espécie em uma população costeira e uma no interior da América do Sul. A população costeira teria originado o clado Geral, enquanto a população do interior pode ter sofrido nova divisão e diversificação em um período mais recente, originando os dois clados internos, associados às bacias hidrográficas.

Os valores de divergência genética entre estas linhagens foram consideráveis se comparados a valores já descritos em trabalhos de filogeografia intraespecífica. Ditchfield (2000) encontrou baixos índices de divergência nucleotídica, entre 1 e 4\%, em 17 espécies de morcegos, com pouca ou nenhuma circunscrição geográfica das populações. Hoffmann e Baker (2001) encontraram duas linhagens bem suportadas em Glossophaga soricina, uma espécie nectarívora da Região Neotropical. Um dos clados incluía amostras da 
América do Sul a leste dos Andes, enquanto o outro era composto por indivíduos da America Central e America do Norte, Jamaica e porção oeste dos Andes. Apesar dos mesmos apresentarem uma divergência genética relativamente alta, de 4,6\%, sua separação era congruente com um dos eventos de soerguimento dos Andes, no fim do período terciário, muito anterior à idade encontrada para $N$. albiventris, que possui médias de divergência de 4,9\%. Similarmente, Hoffmann e Baker (2003) encontraram para as espécies do gênero frugívoro Carollia valores inferiores a $2 \%$ de divergência intraespecífica. Apenas C. castanea apresentou um valor elevado (5,28\%), sendo que este táxon foi recentemente separado em duas espécies (Solari e Baker, 2006). Alternativamente, o morcego hematófago Desmodus rotundus apresenta altos níveis de divergência genética. Martins et al. (2007) encontraram clados geograficamente circunscritos para a espécie, correspondendo aos diferentes biomas brasileiros, cujos haplótipos divergiam em média 6\%. O tempo de divergência entre os clados encontrados foi semelhante, congruente com eventos vicariantes do Pleistoceno.

A Figura 11 representa um esquema da distribuição geográfica dos clados encontrados nas análises filogenéticas, assim como suas áreas de contato, na Guiana e no Peru. As áreas de ocorrência de cada filogrupo foram plotadas sobre o mapa da distribuição das subespécies propostas por Davis (1976) para N. albiventris. Ao se comparar os dois, observa-se claramente uma sobreposição de ocorrência entre o clado Geral e a subespécie N. a. albiventris, cuja distribuição proposta abrange o sul da Venezuela e Guiana, Baixa Bacia Amazônica e costa brasileira. Já o clado encontrado para as demais localidades da Amazônia coincide com a área de distribuição da subespécie N. a. affinis, que inclui a área de drenagem do alto rio Amazonas, o leste dos Andes e a costa norte da América do Sul (Venezuela, Guianas e Suriname). Davis encontrou para os espécimes analisados na região das Guianas e Venezuela uma amplitude significativa nas medidas realizadas. Tal variação poderia ser indicativa da existência de uma outra subespécie (ou linhagem) na região. Entretanto, esta zona foi considerada por Davis como de intergradação, sendo alguns indivíduos classificados como N. a. affinis - áreas costeiras da Venezuela, Guiana e Suriname - enquanto outros seriam representantes de N. a. albiventris - regiões do interior das Guianas. Dessa maneira, N. a. affinis estaria distribuído ao longo da versante leste da cordilheira oriental dos Andes até as proximidades de Caracas, e ao longo da costa norte da América do Sul, até o Suriname. O autor descarta a 
alternativa de tratar a população costeira, de Caracas ao Suriname, como uma unidade taxonômica separada, por não encontrar evidências para a separação.

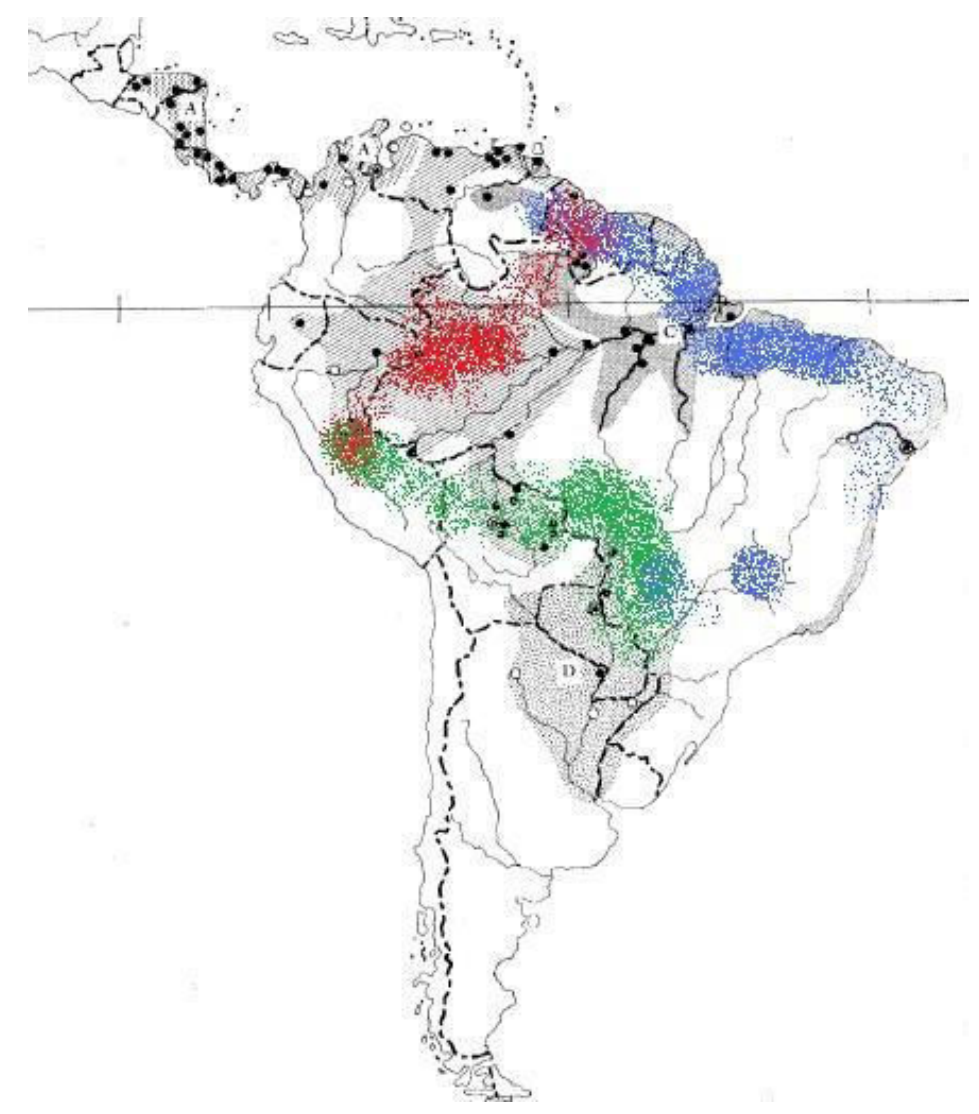

Figura 11. Esquema com a distribuição dos clados encontrados em N. albiventris (áreas coloridas indicativas de cada clado), sobrepostas com as áreas propostas por Davis (1976) para a ocorrência das subespécies (ver Introdução).

Os limites geográficos do clado Amazônia nas análises, entretanto, são mais restritos que a distribuição proposta para a subespécie $N$. a. affinis. Isto porque a maioria dos indivíduos amostrados na região de Madre de Dios, no Peru, encontra-se agrupada no clado Pantanal. Assim, a correspondência geográfica entre o clado Amazônico e N. a. affinis não é absoluta. Contudo, a área de sobreposição encontrada entre os clados Geral e Amazônia é coerente com a zona de contato proposta por Davis para N. a. albiventris e N. a. affinis na região das Guianas. 
Pelos resultados encontrados, a maioria dos indivíduos do Peru não corresponde à mesma linhagem da Alta Bacia Amazônica e, portanto, não pode ser associada à $N$. a. affinis. Acredita-se que esta linhagem que se estende do Pantanal ao Peru corresponda à subespécie N. a. cabrerai, descrita por Davis (1976). Uma confirmação seria possível caso fossem incluídas amostras de localidades mais ao Sul, como Paraguai ou mesmo Paraná, o que infelizmente não foi alcançado no decorrer deste trabalho. Apesar deste clado possivelmente corresponder à subespécie N. a. cabrerai, as distribuições da linhagem do Pantanal e desta subespécie também não se sobrepõem totalmente, já que esta última estaria restrita às bacias dos rios Paraná e Paraguai, não incluindo localidades no Peru. A ocorrência de linhagens simpátricas no Peru também foi descrita para Glossophaga soricina (Hoffmann e Baker, 2001) e para o gênero Artibeus (Patterson et al., 1992).

\section{Origem das linhagens evolutivas do gênero Noctilio}

A busca por uma explicação dos padrões filogeográficos observados para as duas espécies do gênero Noctilio levanta as seguintes questões: Onde surgiu o ancestral comum nas duas espécies de Noctilio existentes hoje? Como se deu e quais os fatores responsáveis pelo processo de diversificação dentro do gênero? Como teria surgido a linhagem piscívora de $N$. leporinus?

Algumas evidências conciliadas de trabalhos anteriores e de resultados obtidos aqui são citadas e contribuem para a elaboração de uma hipótese que explique a história evolutiva deste gênero. Inicialmente, existe a descrição de fósseis de $N$. albiventris datando de 12,5 m.a. na Fauna de La Venta, Colômbia e 7,5 m.a. no conglomerado do Acre, na região de Inãpari, Peru. Para este último sítio fóssil existe a descrição de uma terceira espécie para o gênero, N. lacrimaelunaris (Czaplewski, 1996), ligeiramente menor que N. albiventris, também datando de 7,5 m.a. Apesar do registro fóssil descrever espécimes como pertencentes a $N$. albiventris, estes possuem idades muito anteriores àquelas encontradas para o ACMR da espécie. Mesmo sendo levado em conta que a amostragem não é capaz de abranger toda a diversidade genética da espécie, tais fósseis são muito antigos para representarem espécimes pertencentes às linhagens atuais. As estimativas mais recentes para a idade da linhagem de Noctilio citam valores entre 3 e 4 milhões de anos apenas (Teeling et al., 2005; Jones et al., 2005). A idéia mais plausível é propor que tais fósseis representem uma linhagem ancestral, antecessora à divisão entre $N$. leporinus e $N$. 
albiventris e que, devido ao estado plesiomórfico do hábito alimentar insetívoro, possuía caracteres morfológicos e de dentição similares àqueles encontrados hoje em $N$. albiventris.

A distribuição dos clados encontrados para $N$. albiventris, aparentemente, é influenciada pelas bacias dos rios de planície da América do Sul. A separação geográfica entre tais filogrupos coincide com a zona de contato dessas bacias, onde as linhagens ocorrem em simpatria. Apesar de existirem registros de captura em regiões acima de $1000 \mathrm{~m}$ de altitude, $N$. albiventris é encontrado predominantemente em locais com até 500 metros de altitude (Davis, 1976). Sua distribuição está associada majoritariamente a habitats de floresta com rios de baixa velocidade, córregos e lagoas, devido ao seu hábito insetívoro de lâmina d'agua. Dessa maneira, é possível que $N$. albiventris se distribua de maneira descontínua ao longo da América Latina, e que áreas planálticas possam representar locais pouco propícios para a ocorrência da espécie.

Ao que tudo indica, os tributários da Alta Bacia Amazônica moldam a distribuição de uma linhagem evolutiva, constituída pelas amostras da porção centro-ocidental da Amazônia. Essa linhagem alcança o Peru e provavelmente também pode ser encontrada na área de influência do Rio Guaporé, na divisa entre Brasil e Bolívia. Apesar da amostragem não permitir a confirmação deste fato, os resultados de Davis representam uma evidência, pois o autor descreve para a região de Beni, Bolívia (área 9) indivíduos com maior variação nas medidas aferidas, considerando-os intermediários entre as subespécies $N$. a. affinis e $N$. a. cabrerai. Ao norte, o clado se estende até a Venezuela, na bacia do rio Orinoco, e alcança a bacia do rio Essequibo na Guiana. As bacias dos rios Orinoco e Essequibo parecem ser áreas de co-ocorrência de linhagens. A partir dali inicia-se a distribuição de outra linhagem, que se estende para a Baixa Bacia Amazônica, e inclui as áreas de cerrado brasileiras amostradas. É possível que a distribuição deste clado também inclua a bacia do rio São Francisco, onde está situada a localidade-tipo de $N$. albiventris. No entanto, como se trata de um rio de planalto, a espécie deve ocorrer de maneira heterogênea ao longo da bacia, habitando as áreas de menor variação altitudinal. A terceira linhagem encontrada está associada à bacia do rio Paraguai, e ocupa a região da Planície do Pantanal. A distribuição do clado provavelmente abrange a Bolívia, pois indivíduos desta linhagem podem ser encontrados mais ao norte, no Peru. Dessa maneira, a bacia do rio Guaporé e afluentes pode ser inferida como área de simpatria entre os filogrupos da Amazônia e Pantanal. 
O fato da Bacia Amazônica conter duas linhagens distintas, um na porção centro-ocidental e outro na porção oriental, mostra como a área se comporta de maneira heterogênea. Muitos trabalhos de filogeografia na Região Neotropical também descrevem a Região Amazônica como uma área composta (Cracraft \& Prum, 1988; Bates et al., 1998; Patton et al., 2000; Costa, 2003), seja no que diz respeito à diversificação intraespecífica ou entre espécies de um gênero. Costa (2003) descreve tal padrão para táxons de pequenos mamíferos terrestres. Em Oryzomys megacephalus, Metachirus nudicaudatus e Marmosa murina indivíduos de diversas localidades de Mata Atlântica são geneticamente mais próximos àqueles de Floresta Amazônica do que os últimos são entre si. Para a espécie Micoureus demerarae, os haplótipos da porção leste da Amazônia são mais similares aqueles da Mata Atlântica do nordeste brasileiro do que de outras localidades amazônicas, assim como é observado em $N$. albiventris. Tais processos de diversificação, porém, são explicados por eventos bem anteriores às datas encontradas para origem dos clados de $N$. albiventris.

Acredita-se que o "mosaicismo filogenético" da bacia amazônica, no caso de N. albiventris, pode ser atribuído a uma diferença de habitat existente entre essas grandes regiões. Dessa forma, a linhagem que se distribui na Alta Bacia Amazônica e áreas adjacentes, assim como aquela localizada na Planície do Pantanal, teria sua estratégia alimentar mais associada aos rios e suas regiões de várzea. À medida que os rios alcançam as bordas do continente, outro habitat se configura, devido ao surgimento de deltas e de vastas áreas de estuário, como dos rios Orinoco e Amazonas, por exemplo. Logo, a linhagem distribuída na costa da América do Sul poderia ter um hábito alimentar peculiar, associado às disponibilidades deste ambiente.

O forrageio diferencial no estuário poderia contribuir para uma explicação para a origem da linhagem piscívora de $N$. leporinus. A elevada disponibilidade de peixes e crustáceos em mangues e estuários, e seu poder nutricional maior se comparado aos insetos capturados por $N$. albiventris, pode ter sido um fator crucial para que a piscivoria fosse favorecida e surgisse dentro da população costeira. Gillete (1975), em trabalho sobre a evolução de estratégias alimentares em morcegos, destaca a importância da dualidade de hábitos alimentares no processo de evolução. O autor divide tal processo em quatro passos, desde a insetivoria, que é considerada o hábito ancestral (etapa1), até a conquista de outra especialização alimentar (etapa 4). Neste contexto, $N$. albiventris é incluído na etapa 2, por 
possuir uma insetivoria especializada, alimentando-se de insetos associados a outras potenciais fontes alimentares, no caso, a superfície da água. Paralelamente, $N$. leporinus é incluído na etapa 3 da transição, por utilizar ambas as fontes alimentares, primitiva e alternativa. A etapa 4, que significaria a modificação total do hábito alimentar, ainda não pode ser observada em Noctilio. Dentro desta hipótese, o habito alimentar de $N$. leporinus ainda não atingiu sua fase estacionária, que seria a conquista da piscivoria estrita. Cronologicamente tal raciocínio faz sentido, visto que a modificação na estratégia alimentar aconteceu recentemente na historia evolutiva do táxon.

Entretanto, não apenas a disponibilidade de novos itens alimentares no ambiente deve ser considerada para o surgimento do novo hábito alimentar, mas também a real capacidade dos indivíduos de capturarem outros tipos de presas. Uma das diferenças básicas entre as duas espécies do gênero é o porte, e ele está intimamente associado à estratégia de forrageio adotada. Kalko et al. (1998), apesar de não encontrarem diferenças significativas nos padrões de ecolocação das duas espécies, atribuem alguns comportamentos de forrageio peculiares de N. leporinus ao seu maior tamanho. Assim, o surgimento de uma linhagem com um hábito alimentar distinto seria favorecido pelo fator ambiental, ou seja, a disponibilidade de novos itens alimentares. Porém, indivíduos com alguma vantagem no tamanho seriam mais aptos a iniciarem essa transição. Os dados morfológicos do trabalho de Davis mostraram que as populações da Venezuela e Guianas possuíam elevada variação nas medidas dos indivíduos, diferentemente das demais localidades incluídas na distribuição da subespécie $N$. a. albiventris, onde os indivíduos foram diagnosticados como os de menor tamanho na espécie. O autor associa tal variação à co-ocorrência de $N$. $a$. affinis e $N$. a. albiventris na região, respectivamente nas regiões costeiras e interioranas. Tal vinculação foi uma maneira de explicar a diversidade existente ali, que na verdade pode significar mais do que a simpatria das subespécies. A população dessa área pode ter representado o estoque ancestral de $N$. albiventris. Assim, a partir dela teriam divergido as linhagens reconhecidas hoje.

Similarmente, dessa mesma população pode ter surgido a linhagem piscívora, originando N. leporinus. Conforme os dados moleculares, a única estruturação geográfica evidente na espécie é encontrada na América Central, assim como os poucos registros fósseis existentes. Aparentemente, a ocupação das Ilhas do Caribe e de outras áreas da América Central remete ao surgimento da linhagem, o que explica os haplótipos basais na região. 
Ao se acessar o registro fóssil para $N$. leporinus, constata-se a existência de espécimes apenas em Cuba e Porto Rico. Sabe-se que a distribuição geográfica de $N$. albiventris está limitada à Guatemala, podendo alcançar o México. Ou seja, não existem registros de $N$. albiventris nas Ilhas do Caribe. Baseando-se nestas evidências, acredita-se que o fator determinante para o surgimento de $N$. leporinus foi a colonização de um novo habitat, isolado geograficamente de $N$. albiventris.

Uma das discussões centrais envolvendo a biogeografia histórica do Caribe se refere à determinação dos processos que moldaram sua fauna (Dávalos, 2004). Dentro desse contexto, Hedges e colaboradores (1992) propuseram que a fauna do Caribe apresenta padrões de distribuição concordantes com modelos de dispersão a partir da América do Sul. Outros autores, porém, defendem uma origem através de modelos vicariantes para a biota da região (Iturralde-Vinent e MacPhee, 1999). Contudo, dada sua origem recente, o aparecimento da linhagem piscívora dentro do gênero Noctilio deve ser explicado por dispersão, visto que a partir do Plioceno a configuração geral das Antilhas, incluindo Pequenas Antilhas e Jamaica, já se assemelhava à atual. Variações menores e mais recentes, ou seja, relativas ao Pleistoceno, estariam associadas apenas às mudanças do nível do mar causadas pelas glaciações (Dávalos, 2004).

Dessa maneira, a colonização da região das Pequenas Antilhas por indivíduos da população ancestral de $N$. albiventris provenientes da costa norte da América do Sul pode ser proposta. As glaciações teriam provocado oscilações no nível do mar suficientes para proporcionar a ligação entre o continente e algumas ilhas oceânicas mais próximas da costa, como já afirmado por Koopman (1958). Tais eventos, apesar de não serem essenciais, podem ter contribuído para que $N$. albiventris se deslocasse para algumas dessas ilhas. Adicionalmente, a hipótese levantada sobre o forrageio diferencial na área estuarina pode ter sido um fator importante, permitindo que os indivíduos de $N$. albiventris da população costeira, após atingirem as Ilhas do Caribe, sobrevivessem nesse novo habitat. Ali a linhagem poderia ter se diferenciado, dado o isolamento geográfico necessário da sua população ancestral, e sofrido uma grande irradiação. Posteriormente, presume-se que a linhagem com o novo hábito alimentar atingiu o continente, e ampliou bruscamente sua distribuição geográfica, que se sobrepôs à de sua espécie ancestral. Dávalos (2004) demonstra que a espécie Natalus stramineus também apresenta relações filogenéticas entre o continente e as Pequenas Antilhas condizente com um modelo de 
dispersão a partir da América do Sul. Em trabalho mais recente, Dávalos (2007) utilizou tal modelo de diversificação de linhagens, envolvendo a colonização das Ilhas do Caribe seguida de radiação e recolonização do continente, para explicar o padrão biogeográfico observado para um grupo de morcegos da família Phyllostomidae denominado short-faced bats (subtribo Stenodermatina).

As diversificações ocorridas posteriormente dentro do gênero Noctilio teriam originado uma linhagem no Pantanal e outra na Amazônia Ocidental. Esta última teria ocupado a Alta Bacia Amazônica e dispersado para as bacias dos rios Orinoco e Essequibo, passando a ocorrer em simpatria com a população ancestral que ali habitava. Isso também explica a existência de indivíduos da Guiana pertencentes a duas linhagens distintas. Os dados moleculares incluem apenas um indivíduo da Venezuela, mas este possui uma posição basal nas análises filogenéticas. Complementarmente, a idade estimada para as linhagens é congruente com o modelo de ocupação proposto. Fica em aberto, porém, como ocorreu a separação das linhagens do Pantanal e do Amazonas. Por possuírem idades similares, sua origem pode ser explicada por algum evento vicariante que as isolou no final do Pleistoceno.

A conquista de uma fonte alimentar alternativa nos habitats de estuário leva a crer que a linhagem piscívora divergiu a partir do clado Geral de $N$. albiventris. Mesmo não existindo evidência filogenética que suporte tal parentesco, essa possibilidade não pode ser descartada, visto que esta linhagem é a mais antiga, sendo a única com idade anterior à existência do ACMR de $N$. leporinus. Os outros dois filogupos encontrados em $N$. albiventris possuem tempos de diversificação similares, e posteriores à data de origem da linhagem piscívora.

Os resultados, no entanto, não são totalmente conclusivos, devido à ausência de amostragem na América Central. A existência de outra linhagem de $N$. albiventris nessa região, sendo esta mais antiga que aquelas da América do Sul, falsificaria a interpretação feita com os presentes dados, sugerindo uma origem para ambas as espécies na América Central. 


\section{CONCLUSÕES}

As evidências encontradas neste estudo permitiram a corroboração da hipótese de que $N$. leporinus especiou recentemente. Também foi possível sugerir que a linhagem piscívora divergiu a partir de uma população de $N$. albiventris. A parafilia de $N$. albiventris, evidenciada por Lewis-oritt et al. (2001) e novamente confirmada, também é sugestiva de uma origem de $N$. leporinus a partir de um ancestral pertencente à uma linhagem da espécie-irmã. Foram encontradas três linhagens distintas em N. albiventris. Estas possuem elevados valores de divergência genética (em média 5\%), comparáveis à divergência observada entre $N$. albiventris e $N$. leporinus. A existência dessa estruturação genética e geográfica em $N$. albiventris, com elevados valores de diversidade genética e divergência nucleotidica entre seus clados, além de seu hábito alimentar insetívoro basal à piscivoria (Ferrarezzi \& Gimenez, 1996), corroboram a hipótese desta espécie ter surgido anteriormente na história evolutiva do grupo.

As linhagens evolutivas de $N$. albiventris foram associadas aos diferentes habitats existentes no interior e na costa do continente sul-americano. Assim, os clados da Bacia Amazônica e do Pantanal estariam relacionados às áreas de várzea dos rios de planície. 0 outro clado ocorreria nas áreas mais costeiras, associado aos principais estuários do continente. As estimativas coalescentes apontam a linhagem estuarina como mais antiga que as demais. Diante da ausência de amostras da América Central, este clado foi assumido como o mais antigo na espécie, e a partir disso, uma hipótese para origem da linhagem piscívora foi sugerida.

Acredita-se que o ambiente estuarino teria propiciado um aumento na plasticidade do hábito alimentar na população costeira de $N$. albiventris. Apesar de insetívoro, $N$. albiventris captura suas presas principalmente na lâmina d'água e a elevada disponibilidade de outros itens alimentares nesse ambiente teria favorecido a inclusão de tais itens na dieta dessa população. Mesmo constituindo uma dieta mais nutritiva e vantajosa, a conquista da piscivoria provavelmente está associada não apenas à disponibilidade do ambiente, mas à capacidade do animal em capturar itens maiores que insetos. Assim, se for assumido que indivíduos com maior tamanho foram favorecidos nesse processo de transição, as evidências morfológicas sugerem que a população do norte da América do Sul seria a mais propícia para o surgimento desta linhagem, por 
possuir uma maior variação nas medidas que o restante da distribuição do clado de $N$. $a$. albiventris. Por fim, o isolamento geográfico e a ausência de competição devem ter sido fatores fundamentais para que o processo de especiação se completasse. Assim, em concordância com o que é sugerido pelos dados moleculares, a hipótese mais plausível é que $N$. leporinus tenha se originado nas Ilhas do Caribe, a partir de uma população ancestral de $N$. albiventris proveniente da costa norte da América do Sul. Tal população teria atingido algumas ilhas das Antilhas favorecida pelas oscilações no nível do mar causadas pela glaciações do Pleistoceno. Posteriormente, essa nova linhagem teria atingido o continente e irradiado, passando o ocorrer em simpatria com sua espécie ancestral. As outras duas linhagens de $N$. albiventris teriam aparecido posteriormente, a partir do mesmo estoque ancestral que originou $N$. leporinus.

Baseando-se na hipótese proposta, acredita-se que a população ancestral de $N$. albiventris possuísse uma maior variação morfológica do que a observada atualmente em $N$. albiventris, e tal plasticidade teria favorecido a divergência de uma linhagem com modificação no hábito alimentar. Essa linhagem piscivora-insetívora, com seu hábito alimentar distinto, ocupou um nicho até então inexplorado por morcegos neotropicais. $\mathrm{O}$ surgimento de $N$. leporinus pode inclusive ter causado uma alteração no nicho ecológico de $N$. albiventris, permitindo assim que as duas espécies ocorressem simpatricamente. Possivelmente as diferenças de comportamento observadas entre estas atualmente, tais como época reprodutiva e pico de atividade, sejam um reflexo desse deslocamento de nicho. 


\section{ANEXO}

Anexo 1. Lista de amostras utilizadas no trabalho. *Coleta realizada para complementação de amostras para o projeto. **Localidades das seqüências obtidas no GeneBank .

\begin{tabular}{|c|c|c|c|}
\hline Espécie & Nome da amostra & Localidade & Coletor / Instituição \\
\hline Noctilio leporinus & MVZ 166218 & Montserrat, Caribe & MVZ - Berkeley \\
\hline Noctilio leporinus & AD 932 & Sooretama, ES, Brasil & LABEQ - UFES \\
\hline Noctilio leporinus & AD 1014 & Vitória, ES, Brasil & LABEQ - UFES \\
\hline Noctilio leporinus & AD 42 & João Pessoa, PB, Brasil & LABEC - USP \\
\hline Noctilio leporinus & AD 101 & $\begin{array}{c}\text { Baia Formosa, RN, } \\
\text { Brasil }\end{array}$ & LABEC - USP \\
\hline Noctilio leporinus & AD 102 & $\begin{array}{c}\text { Baia Formosa, RN, } \\
\text { Brasil }\end{array}$ & LABEC - USP \\
\hline Noctilio leporinus & RODOSOL & Guarapari, ES, Brasil & LABEQ - UFES \\
\hline Noctilio leporinus & 98757 & Barima-waini, Guiana & ROM - Canadá \\
\hline Noctilio leporinus & 104207 & Zona do Canal, Panamá & ROM - Canadá \\
\hline Noctilio leporinus & -99 & Zona do Canal, Panamá & ROM - Canadá \\
\hline Noctilio leporinus & 106553 & $\begin{array}{c}\text { Takutu-Essequibo, } \\
\text { Guiana }\end{array}$ & ROM - Canadá \\
\hline Noctilio leporinus & 106606 & $\begin{array}{c}\text { Takutu-Essequibo, } \\
\text { Guiana }\end{array}$ & ROM - Canadá \\
\hline Noctilio leporinus & 106612 & $\begin{array}{c}\text { Takutu-Essequibo, } \\
\text { Guiana }\end{array}$ & ROM - Canadá \\
\hline Noctilio leporinus & 106658 & $\begin{array}{l}\text { Takutu-Essequibo, } \\
\text { Guiana }\end{array}$ & ROM - Canadá \\
\hline Noctilio leporinus & 106671 & $\begin{array}{c}\text { Takutu-Essequibo, } \\
\text { Guiana }\end{array}$ & ROM - Canadá \\
\hline Noctilio leporinus & 106689 & $\begin{array}{c}\text { Takutu-Essequibo, } \\
\text { Guiana }\end{array}$ & ROM - Canadá \\
\hline Noctilio leporinus & 106727 & $\begin{array}{c}\text { Takutu-Essequibo, } \\
\text { Guiana }\end{array}$ & ROM - Canadá \\
\hline Noctilio leporinus & 106740 & $\begin{array}{c}\text { Takutu-Essequibo, } \\
\text { Guiana }\end{array}$ & ROM - Canadá \\
\hline Noctilio leporinus & 106752 & $\begin{array}{l}\text { Takutu-Essequibo, } \\
\text { Guiana }\end{array}$ & ROM - Canadá \\
\hline Noctilio leporinus & 106774 & $\begin{array}{c}\text { Takutu-Essequibo, } \\
\text { Guiana }\end{array}$ & ROM - Canadá \\
\hline Noctilio leporinus & 106775 & $\begin{array}{c}\text { Takutu-Essequibo, } \\
\text { Guiana }\end{array}$ & ROM - Canadá \\
\hline Noctilio leporinus & 109342 & Potaro-Siparuni, Guiana & ROM - Canadá \\
\hline Noctilio leporinus & 112643 & $\begin{array}{l}\text { Demerara-Mahaica, } \\
\text { Guiana }\end{array}$ & ROM - Canadá \\
\hline Noctilio leporinus & 112644 & $\begin{array}{l}\text { Demerara-Mahaica, } \\
\text { Guiana }\end{array}$ & ROM - Canadá \\
\hline Noctilio leporinus & 112701 & $\begin{array}{l}\text { Demerara-Mahaica, } \\
\text { Guiana }\end{array}$ & ROM - Canadá \\
\hline Noctilio leporinus & 113367 & $\begin{array}{l}\text { Demerara-Berbice, } \\
\text { Guiana }\end{array}$ & ROM - Canadá \\
\hline Noctilio leporinus & 113446 & $\begin{array}{c}\text { Demerara-Berbice, } \\
\text { Guiana }\end{array}$ & ROM - Canadá \\
\hline Noctilio leporinus & 113447 & $\begin{array}{c}\text { Demerara-Berbice, } \\
\text { Guiana }\end{array}$ & ROM - Canadá \\
\hline
\end{tabular}




\begin{tabular}{|c|c|c|c|}
\hline Noctilio leporinus & 113675 & $\begin{array}{l}\text { Demerara-Mahaica, } \\
\text { Guiana }\end{array}$ & ROM - Canadá \\
\hline Noctilio leporinus & 113782 & $\begin{array}{c}\text { Demerara-Mahaica, } \\
\text { Guiana }\end{array}$ & ROM - Canadá \\
\hline Noctilio leporinus & 113783 & $\begin{array}{l}\text { Demerara-Mahaica, } \\
\text { Guiana }\end{array}$ & ROM - Canadá \\
\hline Noctilio leporinus & 113837 & $\begin{array}{l}\text { Demerara-Mahaica, } \\
\text { Guiana }\end{array}$ & ROM - Canadá \\
\hline Noctilio leporinus & 97682 & Chiapas, México & ROM - Canadá \\
\hline Noctilio leporinus & 97683 & Chiapas, México & ROM - Canadá \\
\hline Noctilio leporinus & LK02 & $\begin{array}{c}\text { Cândido Mendes, MA, } \\
\text { Brasil }\end{array}$ & LBEM - UFMG \\
\hline Noctilio leporinus & LK03 & $\begin{array}{c}\text { Cândido Mendes, MA, } \\
\text { Brasil }\end{array}$ & LBEM - UFMG \\
\hline Noctilio leporinus & LK04 & $\begin{array}{c}\text { Cândido Mendes, MA, } \\
\text { Brasil }\end{array}$ & LBEM - UFMG \\
\hline Noctilio leporinus & LK05 & $\begin{array}{c}\text { Cândido Mendes, MA, } \\
\text { Brasil }\end{array}$ & LBEM - UFMG \\
\hline Noctilio leporinus & LK06 & $\begin{array}{c}\text { Cândido Mendes, MA, } \\
\text { Brasil }\end{array}$ & LBEM - UFMG \\
\hline Noctilio leporinus & MOL63 & $\begin{array}{c}\text { Queimado, Unaí, MG, } \\
\text { Brasil }\end{array}$ & LBEM - UFMG \\
\hline Noctilio leporinus & EG380 & $\begin{array}{c}\text { Serra de Ibiapaba, Ipu, } \\
\text { CE, Brasil }\end{array}$ & Eliana Gimenez \\
\hline Noctilio leporinus & EG381 & $\begin{array}{c}\text { Serra de Ibiapaba, Ipu, } \\
\text { CE, Brasil }\end{array}$ & Eliana Gimenez \\
\hline Noctilio leporinus & EG384 & $\begin{array}{c}\text { Serra de Ibiapaba, Ipu, } \\
\text { CE, Brasil }\end{array}$ & Eliana Gimenez \\
\hline Noctilio leporinus & KS159 & Araruna, PB, Brasil & Eliana Gimenez \\
\hline Noctilio leporinus & KS162 & Araruna, PB, Brasil & Eliana Gimenez \\
\hline Noctilio leporinus & KS611 & $\begin{array}{c}\text { Santa Teresinha, PB, } \\
\text { Brasil }\end{array}$ & Eliana Gimenez \\
\hline Noctilio leporinus & KS612 & $\begin{array}{c}\text { Santa Teresinha, PB, } \\
\text { Brasil }\end{array}$ & Eliana Gimenez \\
\hline Noctilio leporinus & PEB684 & $\begin{array}{c}\text { Lago Ayapuá, Rio Purus, } \\
\text { AM, Brasil }\end{array}$ & Ana Carolina Pavan* \\
\hline Noctilio leporinus & PEB685 & $\begin{array}{l}\text { Lago Ayapuá, Rio Purus, } \\
\text { AM, Brasil }\end{array}$ & Ana Carolina Pavan* \\
\hline Noctilio leporinus & PEB686 & $\begin{array}{c}\text { Lago Ayapuá, Rio Purus, } \\
\text { AM, Brasil }\end{array}$ & Ana Carolina Pavan* \\
\hline Noctilio leporinus & PEB783 & $\begin{array}{l}\text { Lago Ayapuá, Rio Purus, } \\
\text { AM, Brasil }\end{array}$ & Ana Carolina Pavan* \\
\hline Noctilio leporinus & PEB785 & $\begin{array}{l}\text { Lago Ayapuá, Rio Purus, } \\
\text { AM, Brasil }\end{array}$ & Ana Carolina Pavan* \\
\hline Noctilio leporinus & PEB786 & $\begin{array}{c}\text { Lago Ayapuá, Rio Purus, } \\
\text { AM, Brasil }\end{array}$ & Ana Carolina Pavan* \\
\hline Noctilio leporinus & PEB790 & $\begin{array}{c}\text { Lago Ayapuá, Rio Purus, } \\
\text { AM, Brasil }\end{array}$ & Ana Carolina Pavan* \\
\hline Noctilio leporinus & ALG 15042 & Ji-Paraná, RO, Brasil & FMNH - Chicago \\
\hline Noctilio leporinus & TV57 & $\begin{array}{c}\text { Alfredo Chaves, ES, } \\
\text { Brasil }\end{array}$ & LABEQ - UFES \\
\hline Noctilio leporinus & TV58 & $\begin{array}{c}\text { Alfredo Chaves, ES, } \\
\text { Brasil }\end{array}$ & LABEQ - UFES \\
\hline Noctilio leporinus & TP054 & $\begin{array}{c}\text { Chapada do Araripe, } \\
\text { Crato, CE, Brasil }\end{array}$ & Thieres Pinto \\
\hline Noctilio leporinus & MOL385 & $\begin{array}{c}\text { Porto Seguro, BA, } \\
\text { Brasil }\end{array}$ & LBEM - UFMG \\
\hline
\end{tabular}




\begin{tabular}{|c|c|c|c|}
\hline Noctilio leporinus & **TK18513 & St. George, Grenada & GeneBank \\
\hline Noctilio leporinus & **TK18700 & $\begin{array}{l}\text { Carriacou Island, } \\
\text { Craigston Estate, } \\
\text { Grenadines }\end{array}$ & GeneBank \\
\hline Noctilio leporinus & **TK86669 & $\begin{array}{l}\text { Berbice District, } \\
\text { Dubulay } \\
\text { Ranch, Guiana }\end{array}$ & GeneBank \\
\hline Noctilio leporinus & **TK15708 & $\begin{array}{l}\text { St. Anthony Parish, } \\
\text { Montserrat } \\
\text { Departamento de }\end{array}$ & GeneBank \\
\hline Noctilio leporinus & **TK22848 & $\begin{array}{c}\text { Leôncio Prado, Tingo } \\
\text { Maria,Peru }\end{array}$ & GeneBank \\
\hline Noctilio leporinus & **TK10224 & $\begin{array}{l}\text { Saramacca, Raleigh } \\
\text { Falls,Suriname }\end{array}$ & GeneBank \\
\hline Noctilio leporinus & **TK19126 & $\begin{array}{c}\text { Bolivar, El Manteco, } \\
\text { Venezuela }\end{array}$ & GeneBank \\
\hline Noctilio albiventris & MVZ 193634 & Rio Juruá, AM, Brasil & MVZ - Berkeley \\
\hline Noctilio albiventris & 4539 & $\begin{array}{c}\text { Pantanal do Rio Negro, } \\
\text { MS, Brasil }\end{array}$ & LABEC - USP \\
\hline Noctilio albiventris & PANMO 18 & Pantanal, MS, Brasil & LABEC - USP \\
\hline Noctilio albiventris & PANMO 39 & Pantanal, MS, Brasil & LABEC - USP \\
\hline Noctilio albiventris & PANMO 37 & Pantanal, MS, Brasil & LABEC - USP \\
\hline Noctilio albiventris & PANMO 42 & Pantanal, MS, Brasil & LABEC - USP \\
\hline Noctilio albiventris & FM38 & Poconé, MT, Brasil & LABEC - USP \\
\hline Noctilio albiventris & FM39 & Poconé, MT, Brasil & LABEC - USP \\
\hline Noctilio albiventris & FM40 & Poconé, MT, Brasil & LABEC - USP \\
\hline Noctilio albiventris & FM41 & Poconé, MT, Brasil & LABEC - USP \\
\hline Noctilio albiventris & FM42 & Poconé, MT, Brasil & LABEC - USP \\
\hline Noctilio albiventris & MCU32 & $\begin{array}{l}\text { APA do Curiaú, } \\
\text { Macapá, AP, Brasil }\end{array}$ & Ana Carolina Martins \\
\hline Noctilio albiventris & MCU50 & $\begin{array}{l}\text { APA do Curiaú, } \\
\text { Macapá, AP, Brasil } \\
\text { RPPN Aricari, }\end{array}$ & Ana Carolina Martins \\
\hline Noctilio albiventris & MAP472 & $\begin{array}{c}\text { Tartarugalzinho, AP, } \\
\text { Brasil }\end{array}$ & Ana Carolina Martins \\
\hline Noctilio albiventris & 97928 & $\begin{array}{l}\text { Takutu-Essequibo, } \\
\text { Guiana }\end{array}$ & ROM - Canadá \\
\hline Noctilio albiventris & 98107 & $\begin{array}{l}\text { Takutu-Essequibo, } \\
\text { Guiana }\end{array}$ & ROM - Canadá \\
\hline Noctilio albiventris & 107253 & $\begin{array}{l}\text { Potaro-Siparuni, } \\
\text { Guiana }\end{array}$ & ROM - Canadá \\
\hline Noctilio albiventris & 107254 & $\begin{array}{l}\text { Potaro-Siparuni, } \\
\text { Guiana }\end{array}$ & ROM - Canadá \\
\hline Noctilio albiventris & 107255 & $\begin{array}{l}\text { Potaro-Siparuni, } \\
\text { Guiana }\end{array}$ & ROM - Canadá \\
\hline Noctilio albiventris & 109032 & $\begin{array}{l}\text { Potaro-Siparuni, } \\
\text { Guiana }\end{array}$ & ROM - Canadá \\
\hline Noctilio albiventris & 109033 & $\begin{array}{l}\text { Potaro-Siparuni, } \\
\text { Guiana }\end{array}$ & ROM - Canadá \\
\hline Noctilio albiventris & 111983 & $\begin{array}{l}\text { Potaro-Siparuni, } \\
\text { Guiana }\end{array}$ & ROM - Canadá \\
\hline Noctilio albiventris & 111984 & $\begin{array}{l}\text { Potaro-Siparuni, } \\
\text { Guiana }\end{array}$ & ROM - Canadá \\
\hline Noctilio albiventris & 113781 & $\begin{array}{c}\text { Demerara-Mahaica, } \\
\text { Guiana }\end{array}$ & ROM - Canadá \\
\hline
\end{tabular}




\begin{tabular}{|c|c|c|c|}
\hline Noctilio albiventris & 115675 & $\begin{array}{l}\text { Potaro-Siparuni, } \\
\text { Guiana }\end{array}$ & ROM - Canadá \\
\hline Noctilio albiventris & 115691 & $\begin{array}{l}\text { Potaro-Siparuni, } \\
\text { Guiana }\end{array}$ & ROM - Canadá \\
\hline Noctilio albiventris & MOL65 & $\begin{array}{c}\text { Queimado, Unaí, MG, } \\
\text { Brasil }\end{array}$ & LBEM - UFMG \\
\hline Noctilio albiventris & QUE104 & $\begin{array}{c}\text { Queimado, Unaí, MG, } \\
\text { Brasil }\end{array}$ & LBEM - UFMG \\
\hline Noctilio albiventris & PEB653 & $\begin{array}{c}\text { Lago Ayapuá, Rio Purus, } \\
\text { AM, Brasil }\end{array}$ & Ana Carolina Pavan* \\
\hline Noctilio albiventris & PEB751 & $\begin{array}{c}\text { Lago Ayapuá, Rio Purus, } \\
\text { AM, Brasil }\end{array}$ & Ana Carolina Pavan* \\
\hline Noctilio albiventris & PEB784 & $\begin{array}{c}\text { Lago Ayapuá, Rio Purus, } \\
\text { AM, Brasil }\end{array}$ & Ana Carolina Pavan* \\
\hline Noctilio albiventris & PEB787 & $\begin{array}{c}\text { Lago Ayapuá, Rio Purus, } \\
\text { AM, Brasil }\end{array}$ & Ana Carolina Pavan* \\
\hline Noctilio albiventris & PEB798 & $\begin{array}{c}\text { Lago Ayapuá, Rio Purus, } \\
\text { AM, Brasil }\end{array}$ & Ana Carolina Pavan* \\
\hline Noctilio albiventris & PEB799 & $\begin{array}{c}\text { Lago Ayapuá, Rio Purus, } \\
\text { AM, Brasil }\end{array}$ & Ana Carolina Pavan* \\
\hline Noctilio albiventris & PEB800 & $\begin{array}{c}\text { Lago Ayapuá, Rio Purus, } \\
\text { AM, Brasil }\end{array}$ & Ana Carolina Pavan* \\
\hline Noctilio albiventris & FMNH174497 & $\begin{array}{l}\text { Madre de Dios, Manu, } \\
\text { Maskoitania, Peru }\end{array}$ & FMNH - Chicago \\
\hline Noctilio albiventris & FMNH174498 & $\begin{array}{l}\text { Madre de Dios, Manu, } \\
\text { Maskoitania, Peru }\end{array}$ & FMNH - Chicago \\
\hline Noctilio albiventris & FMNH174499 & $\begin{array}{l}\text { Madre de Dios, Manu, } \\
\text { Maskoitania, Peru }\end{array}$ & FMNH - Chicago \\
\hline Noctilio albiventris & FMNH174500 & $\begin{array}{l}\text { Madre de Dios, Manu, } \\
\text { Maskoitania, Peru }\end{array}$ & FMNH - Chicago \\
\hline Noctilio albiventris & FMNH174501 & $\begin{array}{l}\text { Madre de Dios, Manu, } \\
\text { Maskoitania, Peru }\end{array}$ & FMNH - Chicago \\
\hline Noctilio albiventris & TP040 & Caucaia, CE, Brasil & Thieres Pinto \\
\hline Noctilio albiventris & BR156-41 & $\begin{array}{l}\text { Vila de Maracá, } \\
\text { Mazagão, AP, Brasil }\end{array}$ & Adalberto Césari \\
\hline Noctilio albiventris & BR156-43 & $\begin{array}{l}\text { Vila de Maracá, } \\
\text { Mazagão, AP, Brasil }\end{array}$ & Adalberto Césari \\
\hline Noctilio albiventris & ${ }^{* *}$ TK86633 & $\begin{array}{l}\text { Berbice District, } \\
\text { Dubulay } \\
\text { Ranch, Guiana } \\
\text { Provincia Leoncio }\end{array}$ & GeneBank \\
\hline Noctilio albiventris & **TK22849 & $\begin{array}{c}\text { Prado, Tingo Maria, } \\
\text { Peru }\end{array}$ & GeneBank \\
\hline Noctilio albiventris & ${ }^{* * T K 17528}$ & Paramaribo, Suriname & GeneBank \\
\hline Noctilio albiventris & **TK19032 & $\begin{array}{c}\text { Bolivar, El Manteco, } \\
\text { Venezuela }\end{array}$ & GeneBank \\
\hline
\end{tabular}


Anexo 2. Lista de primers utilizados para amplificação e seqüenciamento da região $d$-loop e do gene citocromo $b .{ }^{*}$ desenvolvido no presente estudo. Int = primers internos.

\begin{tabular}{ccc}
\hline PRIMER & REGIÃO & SEQUÊNCIA \\
\hline BrDI L & $d$-loop & 5' CCCAAAGCTGAAATTCTACTTAAACTA 3' \\
BrDI H & $d$-loop & 5' ATGACCCTGAAGAAAGAACCAG 3' \\
BAT 05A & citocromo b & 5' CGACTAATGACATGAAAAATCACCGTTG 3' \\
BAT 04A - int & citocromo b & 5' GAGGACAAATATCATTCTGAGGAGCTAC 3' \\
BAT 16A - int & citocromo b & 5' ATTAAGCCAGAATGATACTTCCTTTTT 3' \\
BAT 665 ${ }^{*}$ int & citocromo b & 5' CCTACCACACTATTAAGGACA 3' \\
BAT 14A & citocromo b & 5' GGTCTTGTAAACCGGCAAAGGGAATA 3' \\
\hline
\end{tabular}

Anexo 3. Protocolos e perfis de temperatura utilizados para as reações de PCR para os dois fragmentos analisados.

\begin{tabular}{ccc|cc}
\hline \multicolumn{3}{c|}{ PROTOCOLO } & \multicolumn{2}{c}{ PERFIL } \\
\hline Reagente & citocromo b & d-loop & Etapa & Tempo/Temperatura \\
\hline tampão & $1 \mathrm{X}$ & $1 \mathrm{X}$ & 1 (denatur. inicial) & $7 \mathrm{~min} \mathrm{a} 94^{\circ} \mathrm{C}$ \\
dNTP & $0,2 \mathrm{mM}$ & $0,16 \mathrm{mM}$ & 2 (denaturação) & 30 seg a $94^{\circ} \mathrm{C}$ \\
primer & $0,5 \mu \mathrm{M}$ & $0,5 \mu \mathrm{M}$ & 3 (anelamento) & 45 seg a $54^{\circ} \mathrm{C}$ \\
Cloreto de magnésio & $3 \mathrm{mM}$ & $2,5 \mathrm{mM}$ & 4 (extensão) & 1 min 10 seg a $72^{\circ} \mathrm{C}$ \\
Taq Polimerase & 1 unidade & 1 unidade & 5 (extensão final) & $10 \mathrm{~min} \mathrm{a} 72^{\circ} \mathrm{C}$ \\
\hline
\end{tabular}

Tampão 10X= 200mM Tris-HCl pH8,4; 500mM KCl.

Anexo 4. Protocolo adotado para a Reação de Purificação de produto de PCR.

\begin{tabular}{|c|c|c|c|}
\hline \multicolumn{2}{|c|}{ PROTOCOLO } & \multicolumn{2}{|r|}{ PERFIL } \\
\hline PCR & Enzima & Etapa & Tempo/Temperatura \\
\hline & 1 unidade de SAP & 1 & $60 \mathrm{~min}$ a $37^{\circ} \mathrm{C}$ \\
\hline Para cada $10 \mu \mathrm{L}$ & 10 unidades de Exo I & 2 & $15 \min$ a $80^{\circ} \mathrm{C}$ \\
\hline
\end{tabular}




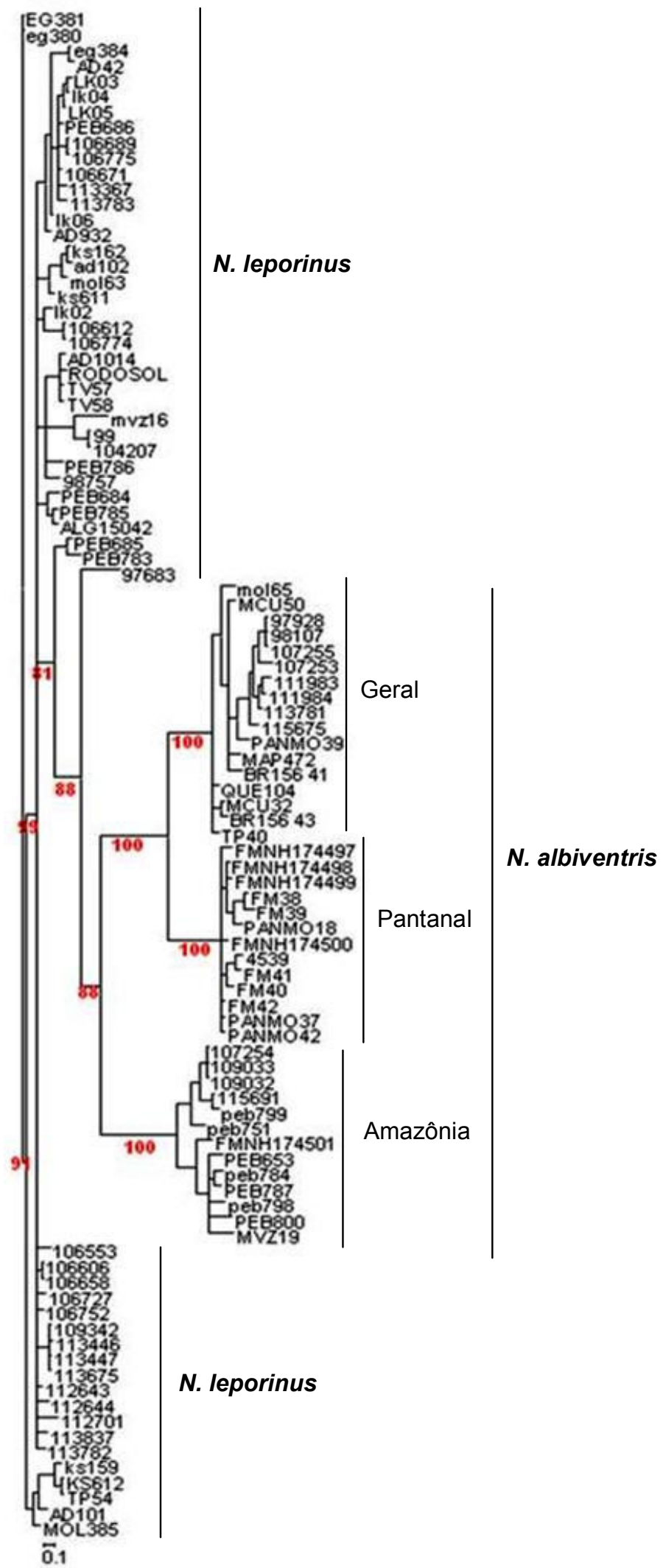

Anexo 5. Resultado da análise bayesiana para a região $d$-loop. 


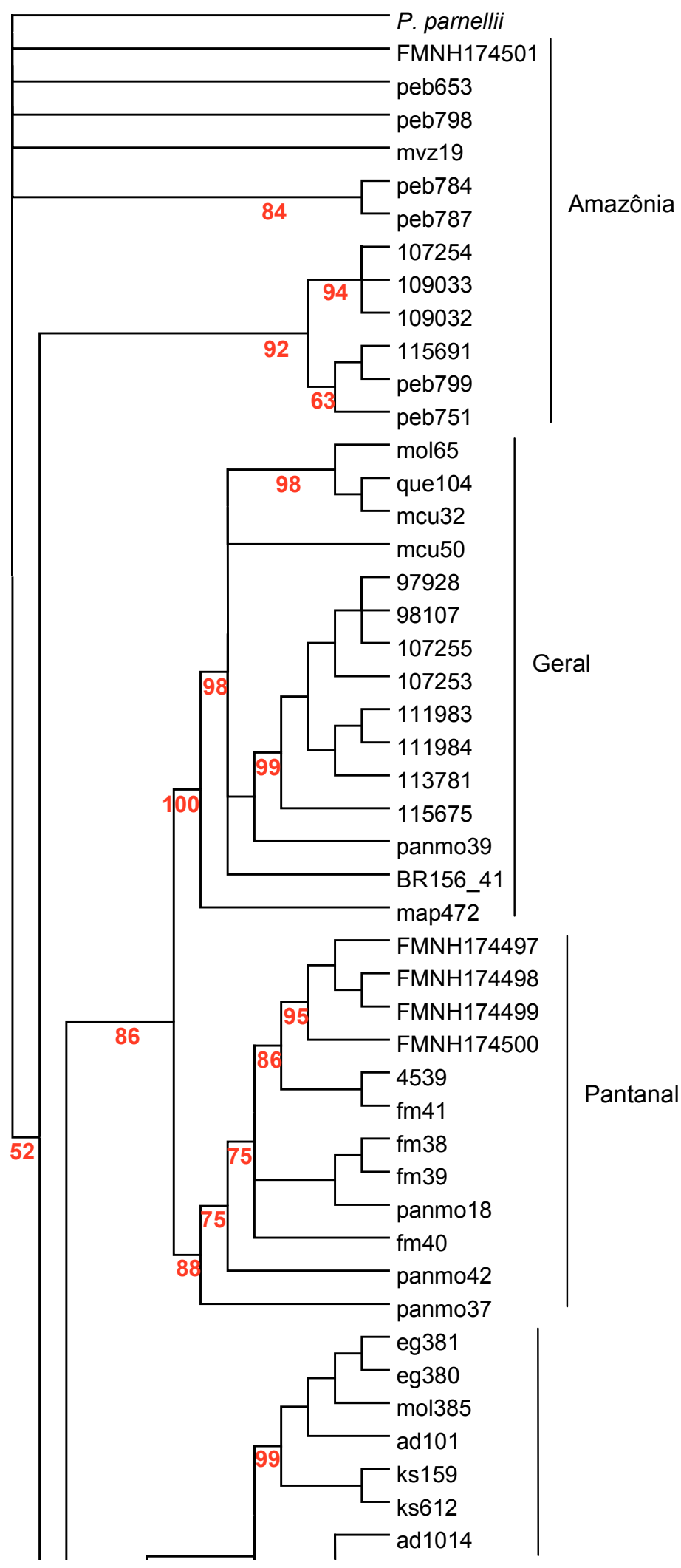




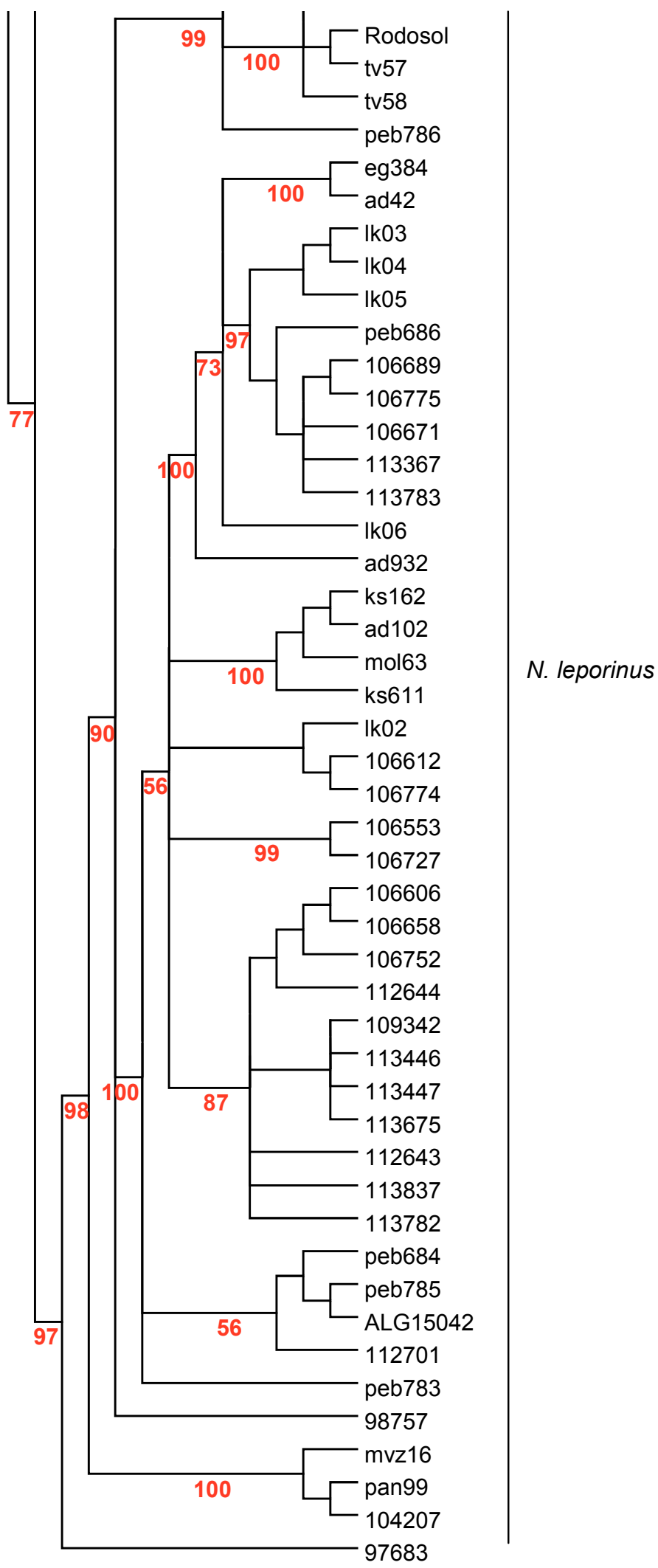

Anexo 6. Topologia da árvore encontrada por análise bayesiana para os dados concatenados. Os valores dos ramos representam o suporte por Bayesian Posterior Probability. 


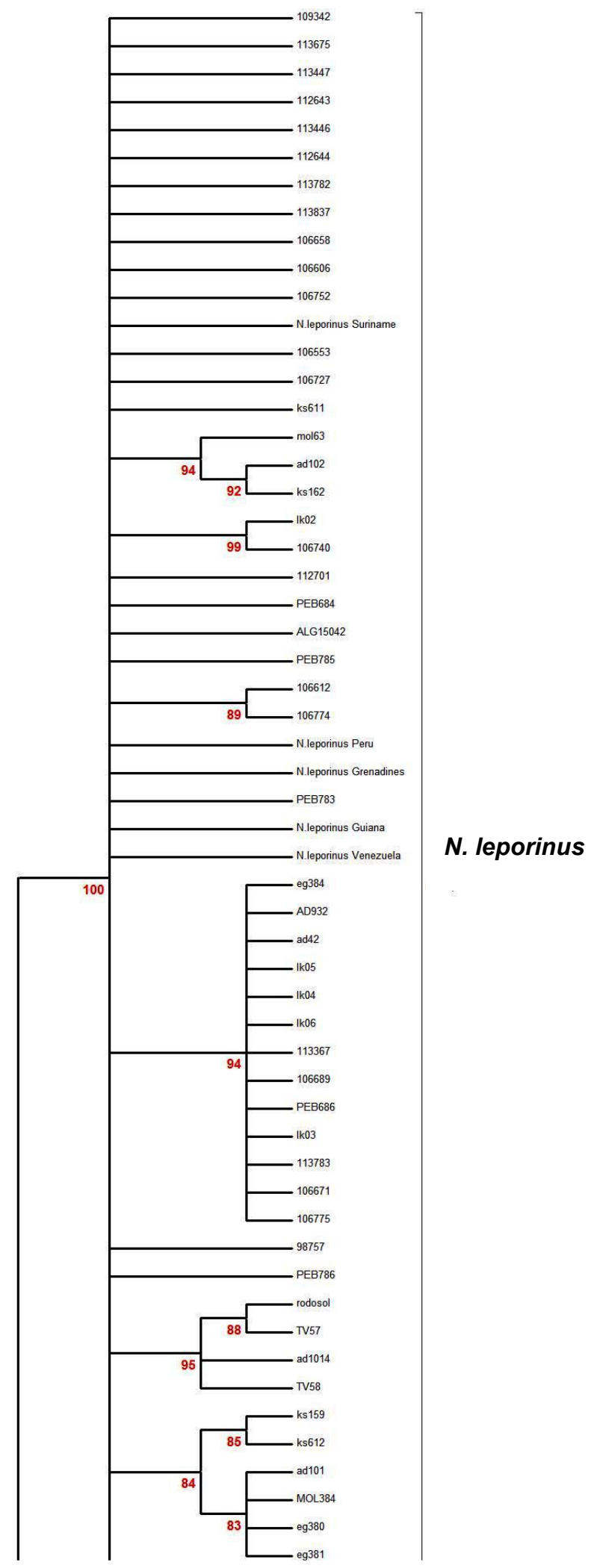




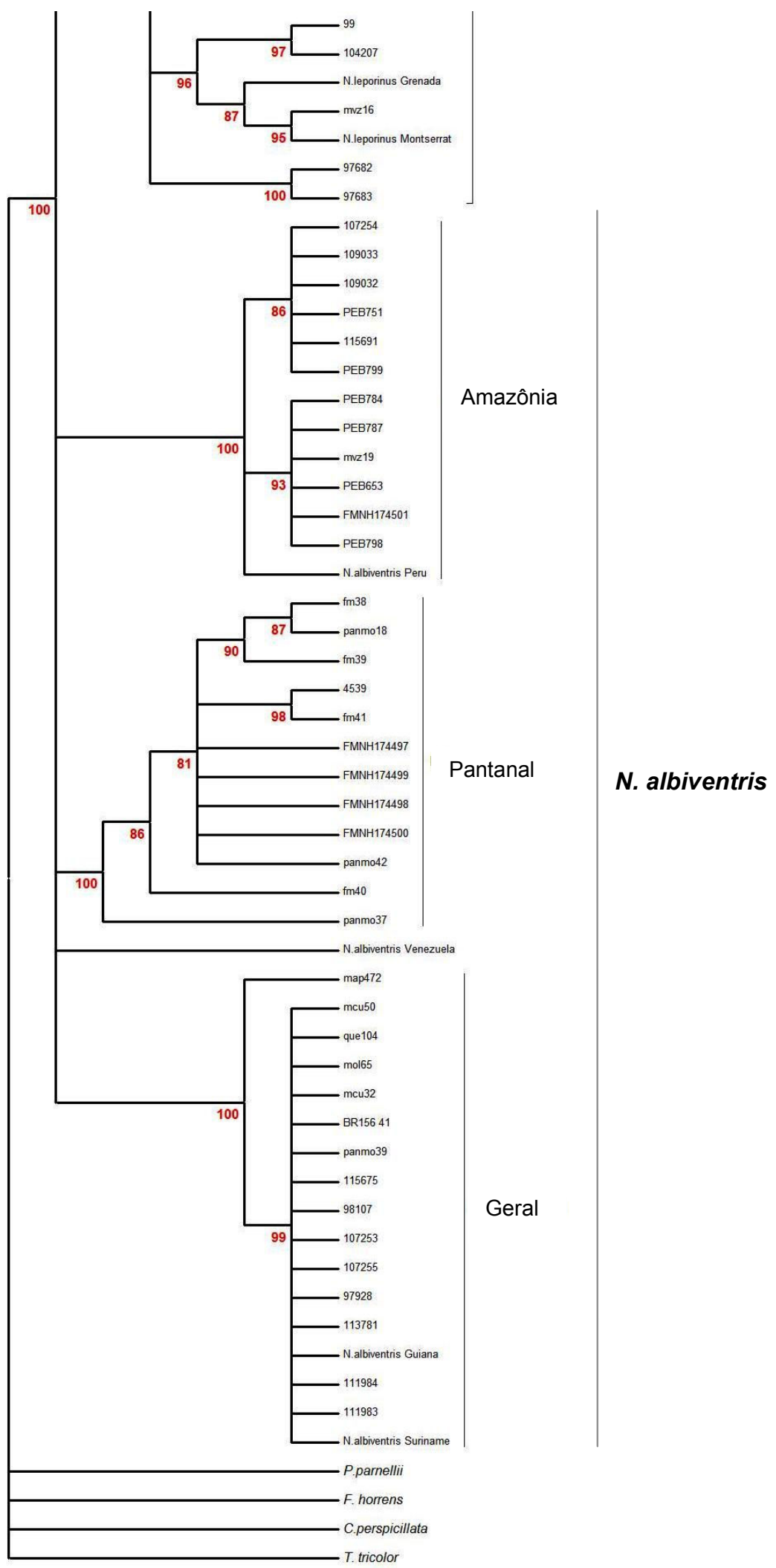

Anexo 7. Consenso de maioria realizado através do método de distância (Neighbor-joining) do gene citocromo $b$, indicando os clados com suporte acima de $80 \%$. 


\section{REFERÊNCIAS BIBLIOGRÁFICAS}

Avise, J.C. 1989. "Gene trees and organismal histories: a phylogenetic approach to population biology." Evolution 43: 1192-1208.

Avise, J.C. 1994. "Molecular markers, natural history and evolution. New York, Chapman \& Hall."

Avise, J.C. 2000. "Phylogeography: the history and formation of species. Harvard University Press."

Bates, J.M., Hackett, S.J., et al. 1998. "Area-relationships in the Neotropical lowlands: an hypotheses based on raw distribution of passerine birds." Jornal of Biogeography 25: 783-93.

Bloedel, P. 1955. "Hunting methods of fish-eating bats, particularly Noctilio leporinus." Journal of Mammalogy 36: 390-399.

Bordignon, M.O. 2001. "Padrão de atividade, comportamento de forrageio, dieta, reprodução e coloração da pelagem em Noctilio leporinus (Chiroptera, Noctilionidae) na Baía de Guaratuba, Paraná. Tese de Doutorado, Universidade Federal do Paraná. Orientador: Dr. Emygdio L. A. Monteiro-Filho.".

Brooke, A.P. 1994. "Diet of the fishing bat, Noctilio leporinus (Chiroptera: Noctilionidae)." Journal of Mammalogy 75(1): 212-218.

Brown, J.H. 1968. "Activity patterns of some Neotropical bats." Journal of Mammalogy 49: 754-757.

Bruford, M.W., Hanotte, O., et al. 1992. "Single-locus and multilocus DNA fingerprinting. In: Molecular genetic analyses of populations. A practical Approach. A.R. Hoelzel (Ed.). IRL Press, Oxford." 225-269.

Carter, D.C., Pine, R.H., et al. 1966. "Notes on Middle American bats." Southwestern Nat 11: 488-499.

Costa, L.P. 2003. "The historical bridge between the Amazon and the Atlantic Forest of Brazil: a study of molecular phylogeography with small mammals." Journal of Biogeography 30: 71-86.

Cracraft, J. and Prum, R.O. 1988. "Patterns and processes of diversification: speciation and historical congruence in some Neotropical Birds." Evolution 42(3): 603-620.

Czaplewski, N.J. 1996. "Opossums (Didelphidae) and bats (Noctilionidae and Molossidae) from the late Miocene of the Amazon Basin." Journal of Mammalogy 77: 84-94.

Czaplewski, N.J. 1997. "Chiroptera. In: Vertebrate Paleontology in the Neotropics: The Miocene Fauna of La Venta, Colombia, ed. Kay, R. F., Madden, R. H., Cifelli, R. L., e Flynn, J. J., pp. . Washington, D.C., Smithsonian Institution Press." 410-431. 
D’Orbigny, A. 1836. "Mammifères. In: Voyage dan L’Amerique Meridionale." 4(2): 9-52.

Dávalos, L.M. 2004. "Phylogeny and Biogeography of Caribbean Mammals." Biological Journal of the Linnean Society 81: 373-394.

Dávalos, L.M. 2007. "Short-faced bats (Phyllostomidae: Stenodermatina): a Caribbean radiation of strict frugivores." Journal of Biogeography 34: 364-375.

Davis, W.B. 1973. "Geographic variation in the fishing bat, Noctilio leporinus." Journal of Mammalogy 54: 862-874.

Davis, W.B. 1976. "Geographic variation in the lesser Noctilio, Noctilio albiventris (Chiroptera)." Journal of Mammalogy 57: 687-707.

Desmarest, A.G. 1818. "Noctilion ou bec de lievre." Nouv. Dict. d'Hist. Nat 23: 14-16.

Ditchfield, A.D. 2000. "The comparative phylogeography of Neotropical mammals: patterns of intraespecific mitochondrial DNA variation among bats contrasted to nonvolant small mammals." Molecular Ecology 9: 1307-1318.

Ditchfield, A.D. and Burns, K. 1998. "DNA Sequences Reveal Phylogeographic Similarities of Neotropical Bats and Birds." Journal of Comparative Biology 3(2): 165170.

Edwards, S.V. and Beerli, P. 2000. "Perspective: gene divergence, population divergence, and the variance in coalescence time in phylogeographic studies." Evolution 54(6): 1839-1854.

Emmons, L. 1990. "Neotropical rainforest mammals: a field guide. University of Chicago Press."

Ewing, B. and Green, P. 1998. "Basecalling of automated sequencer traces using Phred II. Error probabilities." Genome Research 8: 186-194.

Excoffier, L., Laval, G., et al. 2006. "Arlequin ver 3.1: An Integrated Software Package for Population Genetics Data Analysis. Computational and Molecular Population Genetics Lab (CMPG), Institute of Zoology, University of Berne, Switzerland."

Ferrarezzi, H. and Gimenez, E.A. 1996. "Systematic Patterns and the evolution of feeding habits in Chiroptera (Archonta: Mammalia)." J. Comp. Biol. 1(3-4): 75-94.

Forman, G.L. 1973. "Studies of gastric morphology in North American Chiroptera (Emballonuridae, Noctilionidae, Phyllostomidae)." Journal of Mammalogy 54: 909923.

Fu, Y.X. 1997. "Statistical tests of neutrality against population growth, hitchhiking and background selection." Genetics 147:915-925.

Gillete, D.D. 1975. "Evolution of feeding strategies in bats." Tebiwa 18(1): 39-48. 
Goodwin, G.G. and Greenhall, A.M. 1961. "A review of the bats of Trinidad and Tobago." Bulletin of the American Museum of Natural History 122: 187-301.

Gordon, D., Abajian, C., et al. 1998. "Consed: A graphical tool for sequence finishing." Genome Research 8: 195-202.

Green, P. 1994. "Phrap

(www.genome.washington.edu/UWGC/analysistools/phrap.htm)."

Hedges, S.B., Hass, C.A., et al. 1992. "Caribbean biogeography: Molecular evidence for dispersal in West Indian terrestrial vertebrates " Proc Natl Acad Sci U S A 89: 190913.

Hoffmann, F.G. and Baker, R.J. 2001. "Systematics of bats of the genus Glossophaga (Chiroptera: Phyllostomidae) and phylogeography in G. soricina based on the cytochrome b gene." Journal of Mammalogy 82: 1092-1101.

Hoffmann, F.G. and Baker, R.J. 2003. "Comparative phyllogeography of short-tailed bats (Carollia: Phyllostomidae)." Molecular Ecology 12: 3403-3414.

Hoffmann, F.G., Owen, J.G., et al. 2003. "mtDNA perspective of chromosomal diversification and hybridization in Peters' tent-making bat (Uroderma bilobatum : Phyllostomidae)." Molecular Ecology 12: 2981-2993.

Hood, C.S. and Jones, J.K., Jr. 1984. "Noctilio leporinus." Mammalian Species 216: 1-7.

Hood, C.S. and Pitocchelli, J. 1983. "Noctilio albiventris." Mammalian Species 197: 1-5.

Hooper, E.T. and Brown, J.H. 1968. "Foraging and breeding in two sympatric species of Neotropical bats, genus Noctilio." Journal of Mammalogy 49: 310-312.

Iturralde-Vinent, M.A. and MacPhee, R.D.E. 1999. Paleogeography of the Caribbean region: implications for Cenozoic biogeography. Bulletin of the American Museum of Natural History 238: 1-95.

Jones, J.K., Jr., Smith, J.D., et al. 1973. "Annotated checklist of mammals of the Yucatan Peninsula, Mexico. 1. Chiroptera. Ocass. Papers Museum."

Jones, K.E., Bininda-Emonds, O.R.P., et al. 2005. "Bats, clocks, and rocks: diversification patterns in Chiroptera." Evolution 59(10): 2243-2255.

Kalko, E.K.V., Schnitzler, H., et al. 1998. "Echolocation and foraging behavior of the lesser bulldog bat, Noctilio albiventris: preadaptations for piscivory?" Behav. Ecol. Sociobiol 42: 305-319.

Koopman, K.F. 1958. "Land bridges and ecology in bat distribution on islands off the northern coast of South America." Evolution 12(4): 429-439. 
Kuhner, M.K., Yamato, J., et al. 1998. "Maximum likelihood estimation of population growth rates based on the coalescent." Genetics 149: 429-434.

Lewis-Oritt, N., Baker, R.J., et al. 2001. "Molecular evidence for evolution of piscivory in Noctilio (Chiroptera: Noctilionidae)." Journal of Mammalogy 82(3): 748-759.

Linnaeus, C. 1758. "Systema naturae per regna tria naturae, secundum classes, ordines, genera, species, cum characteribus, differentiis, synonymis, locis." 1: 1-824.

Linnaeus, C. 1766. "Systema naturae per regna tria naturae, secundum classes, ordines, genera, species, cum characteribus, differentiis, synonymis, locis." 1(1): 1-532.

Martin, R.A. 1972. "Synopsis of late Pliocene and Pleistocene bats of North America and the Antilles." American Midland Natura 87: 326-335.

Martins, F.M., Ditchfield, A.D., et al. 2007. "Mitochondrial DNA phylogeography reveals marked population structure in the common vampire bat, Desmodus rotundus (Phyllostomidae)." Journal of Zoological Systematics and Evolution 45(4): 372-378.

Moraes-Barros, N., Silva, J.A.B., et al. 2006. "Comparative phylogeography of the Atlantic Forest endemic sloth (Bradypus torquatus) and the widespread three-toed sloth (Bradypus variegatus) (Bradypodidae, Xenarthra)." Genética 126: 189-98.

Nei, M. and Kumar, S. 2000. "Molecular Evolution and Phylogenetics. Oxford University Press, New York."

Nielsen, R. 2002. "MDIV software. (http:// www.biom.cornell.edu/Homepages/Rasmus_Nielsen/files.html)."

Nogueira, M.R. e Pol, A. 1998. "Observações sobre os hábitos de Rhynchonycteris naso (Wied-Neuwied, 1820) e Noctilio albiventris Desmarest, 1818 (Mammallia, Chiroptera)." Revista Brasileira de Biologia 58(3): 473-480.

Nowak, R.M. 1994. "Walker's Bats of the World. The Johns Hopkins University Press. Baltimore and London." 123-125.

Olfers, I.v. 1818. "Bemerkungen zu Illiger's Ueberblick der Säugthiere nach ihrer Vertheilung uber die Welttheile, rück-sichtlich Südamericanischen Arten In: W. L. Eschwege's Journal von Brasilien. Neue Bibliothek " 15(2): 192-237.

Osgood, W.H. 1910. "Mammals from the coast and island of the northern South America." Field Mus of Nat Hist, Zool. Ser. 10: 23-32.

Patterson, B.D., Pacheco, V., et al. 1992. "On the origin of the western slope region of endemism: systematics of fig-eating bats, genus Artibeus." Memorias del Museo de Historia Natural (Lima) 21: 189-205.

Patton, J.L., da Silva, M.N.F., et al. 2000. "Mammals of the Rio Juruá and the evolutionary and ecological diversification of Amazonia." Bulletin of the American Museum of Natural History 244: 1-306. 
Posada, D. and Crandall, K.A. 1998. "ModelTest: testing the model of DNA substitution." Biolnformatics 14: 817-818.

Ronquist, F., Huelsenbeck, J.P., et al. 2005. "MRBAYES 3.1: Bayesian phylogenetic inference under mixed models.

(http://mrbayes.csit.fsu.edu/download.php)."

Rozas, J., Sánchez-DelBarrio, J.C., et al. 2003. "DNAsp, DNA polymorphism analyses by the coalescent and other methods." Biolnformatics 19: 2496-2497.

Sambrook, K.J., Russel, D.W., et al. 2001. "Molecular Cloning: a Laboratory Mannual. CSHL, New York, USA.".

Shimodaira, H. and Hasegawa, M. 1999. "Multiple Comparisons of Log-Likelihoods With Applications to Phylogenetic Inference." Molecular Biology and Evolution 16(8): 1114-1116.

Silva Taboada, G. 1979. "Los murciélagos de Cuba. Acad. Cien. Cuba, Havanna xiii + 423."

Simmons, N.B. 2005. "Order Chiroptera. In: Mammal species of the World: a taxonomic and geographic reference. Eds. D.E. Wilson and D.M Reeder. $3^{a}$ ed, vol 1. Johns Hopkins University Press."

Solari, S. and Baker, R.J. 2006. "Mitochondrial DNA Sequence, Kariotipic, and Morphological Variation in the Carollia castanea Species Complex (Chiroptera:Phyllostomidae) with Description of a New Species." Occasional Papers of Museum of Texas Tech University 254: 1-16.

Swofford, D.L. 2002. " PAUP*. Phylogenetic Analysis Using Parsimony (*and other metods). Version 4. Sinauer Associates, Sunderland, Massachusetts.".

Tajima, F. 1989. "Statistical method for testing the neutral mutation hypothesis by DNA polymorphism." Genetics 123:585-595.

Tajima, F. 1993. "Simple Methods for Testing the Molecular Evolutionary Clock Hypothesis." Genetics 135(2): 599-607.

Tamura, K., Dudley, J., et al. 2007. "MEGA: Molecular Evolutionary Molecular Analysis, version 4.0. Center for Evolutionary Functional Genomics, Biodesign Institute, Arizona State University."

Tamura, K. and Nei, M. 1993. "Estimation of the number of nucleotide substitutions in the control region of mitochondrial DNA in humans and chimpanzees." Mol. Biol. Evol. 10: $512-526$.

Teeling, E.C., Springer, M.S., et al. 2005. "A Molecular Phylogeny for Bats Illuminates Biogeography and the Fossil Record." Science 307: 580-584. 
Vahl, M. 1797. "Beskrivelse paa tree nye Arter Flagermuse." Skrivt. Naturhist.-Selskabet Kjobenhavn 4: 121-138.

Vaughan, T.A., Ryan, J.M., et al. 2000. "Mammalogy, fourth edition."

Voss, R.S. and Emmons, L.H. 1996. "Mammalian Diversity in Neotropical Lowland Rainforests: A Preliminary Assessment." Bulletin of the American Museum of Natural History 230: 1-115.

Xia, X. and Xie, Z. 2001. "DAMBE: Data analysis in molecular biology and evolution." Journal of Heredity 92: 371-373.

Zwickl, D.J. 2006. "GARLI: Genetic algorithm approaches for the phylogenetic analysis of large biological sequence datasets under the maximum likelihood criterion. Ph.D. dissertation, The University of Texas at Austin.

(www.bio.utexas.edu/faculty/antisense/garli/Garli.html)." 